\title{
The skipper butterflies (Lepidoptera: Hesperiidae) of the Reserva Ecológica Leonelo Oviedo, San José, Costa Rica
}

\author{
Luis Ricardo Murillo-Hiller ${ }^{1,2,3 *}$, Oscar Antonio Segura-Bermúdez ${ }^{1}$, Juan Diego Barquero \& \\ Federico Bolaños ${ }^{1,2}$ \\ 1. Escuela de Biología, Universidad de Costa Rica, 11501-2060, San José, Costa Rica; luis.murillohiller@ucr.ac.cr, \\ oscar.segurabermudez@ucr.ac.cr, juanbarquero2@gmail.com, federico.bolanos@ucr.ac.cr \\ 2. Museo de Zoología, Universidad de Costa Rica. \\ 3. Mariposario de la Escuela de Biología. \\ * Correspondence
}

Received 27-II-2018. Corrected 18-I-2019. Accepted 06-II-2019.

\begin{abstract}
Hesperiidae is one of the most diverse families of butterflies in Costa Rica, with approximately 486 species. Even so, there are few butterfly lists where this group has been included. In this paper, we present information on seasonality, abundance and natural history features of this family for the Leonelo Oviedo Ecological Reserve (RELO), a 2 ha forest embedded in an urban matrix. Over the course of two years, a monthly sampling was carried out on a $270 \mathrm{~m}$ trail across the Reserve from 08:00 to 12:00, collecting all the individuals located within $5 \mathrm{~m}$ on each side of the trail. To better represent the richness, individuals were also randomly collected for more than ten years, but the butterflies collected in this way were not included in the statistical analysis. Photographs were taken of all the species in order to provide an identification guide. For the cryptic species, drawings and dissections of the genitalia were made. For the community indexes we used Microsoft Excel and the Shannon index with base two logarithm. For the summary of the monthly data analysis were done according to dry and wet season. For a comparison of richness and abundance we did a g-test to evaluate if there are differences between seasons; however, with the use of the $\mathrm{R}$ package vegan a hierarchical cluster analysis was done using the Jaccard index with Wards minimum variance agglomerative method. With $\mathrm{R}$ package pvclust the uncertainty of the clusters based on a bootstrap with 10000 iterations. 423 individuals of 49 species were included in the statistical analysis, from a total of 435 individuals of 58 species. A tendency to greater richness and abundance of skippers was found during the dry season. Through the cluster analysis, it was possible to determine that in relation to the diversity of skippers, both wet seasons are grouped significantly $(\mathrm{P}=0.05)$. The dry seasons are also grouped significantly $(\mathrm{P}=0.05)$. The reserve has connectivity with other green areas via a stream. During the wet season, plant growth increases connectivity, which could lead to the entry of new individuals of different species that are not permanent residents of RELO and establish small populations, increasing the richness and abundance of species. This added to the variation in the occurrence of some species of butterflies in response to seasonal variations and differences in the availability of resources in different seasons explains the grouping of species between seasons.
\end{abstract}

Key words: $\beta$-biodiversity; conservation; species richness; urban forest reserve; bio-indicators.

Murillo-Hiller, L. R., Segura-Bermúdez, O.A., Barquero, J. D. \& Bolaños, F. (2019). The skipper butterflies (Lepidoptera: Hesperiidae) of the Reserva Ecológica Leonelo Oviedo, San José, Costa Rica. Revista de Biología Tropical, 67(2) Suplemento, S228-S248.

The butterflies of the family Hesperiidae, commonly known as skippers, constitute a group of diurnal lepidopterans although some species are known to fly at dusk, dawn and night (DeVries, 1983; Austin, 2008). In Costa Rica it is one of the most diverse families, alongside Nymphalidae (Vega, 2012), with approximately 486 species (Chacón \& 
Montero, 2007). Morphologically, they can be distinguished by a number of specific features: a wingspan of less than $55 \mathrm{~mm}$, a robust body compared with the wings, small and wellspaced eyes, thorax usually larger than the abdomen, and particularly the presence of a hook at the distal end of the antenna (MurilloHiller, 2008).

The first published list of skippers for Costa Rica was that by Godman \& Salvin (1887-1901) with 166 species, followed by Fulton (1966) who reported 45 species, and more recently DeVries (1983) with 350 species. From the Central Valley of Costa Rica Vega \& Gloor (2001) reported 65 species from El Rodeo, Vega (2006) 42 species from Los Cerros de Escazú, Sánchez, Duran \& Vega (2008) 36 species from La Carpintera, Vega (2012) 35 species from El Rodeo and finally Nishida, Nakamura, \& Morales (2009) reported 65 species from the same site as the present study.

Butterflies and skippers are considered good indicators of diversity of other insect groups such as Hymenoptera, as well as other taxa (Kerr, Sugar, \& Packer, 2000). Also noteworthy is the importance of butterflies as bioindicators in showing the conditions and changes that occur in a given habitat, due to their high sensitivity and close relationship with plants (Pearson, 1994).

Species lists of skippers are generally absent from butterflies studies in Costa Rica. Additionally, the only research about skippers carried out in the Reserva Ecológica Leonelo Oviedo was done with an opportunistic methodology (Nishida et al., 2009). Therefore, this study presents an assessment of the current state, trough a systematic sampling of the Hesperiidae of the reserve. Also, seasonality, abundance and natural history traits are presented.

\section{MATERIALS AND METHODS}

The study site (Fig. 1a and Fig. 1b) is the Reserva Ecológica Leonelo Oviedo (RELO) on the Campus of the University of Costa Rica, San Pedro, San José (09 $56^{\prime} 15^{\prime \prime}$ N \& $84^{\circ} 03^{\prime} 00^{\prime}$ 'W). It consists of a 2 ha. urban reserve immersed in the city and its biological connectivity with others natural areas is limited to the poor vegetation along the Los Negritos stream. The area used to be a shaded coffee plantation, which subsequently was cut to begin a forest regeneration project in 1965 (DiStéfano, Nielsen, Hoomans, \& Fournier, 1996). The RELO has an area of 2 ha classified as Premontane Moist Forest. The average annual rainfall is between 2000 and $4000 \mathrm{~mm}$ and the temperature oscillates between 17 and $24{ }^{\circ} \mathrm{C}$ (Bolaños, Watson, \& Tosi, 2005). Its altitude is $1200 \mathrm{~m}$ and is crossed by two creeks, Los Negritos and Pacayas and because of that it remains humid areas even during the dry season.

An adaptation of the transect sampling of Pollard (1997) was carried out during two years, from March $24^{\text {th }}, 2004$ to March $31^{\text {st }}$, 2006. Samples were taken with a butterfly net by walking through an existing trail of $270 \mathrm{~m}$ (Fig. 2) and collecting all individuals that flew through it, within $5 \mathrm{~m}$ of the trail. The complete transect was done, from 08:00 to 12:00, choosing a sunny day each month. During the sampling day the transect was done completely 12 times. From the total sampling period, only four months (July 2004, December 2004, March 2005 and May 2005) were not sampled due to administrative or logistical inconveniences. For a summary of the results the samples were summed in relation to dry (December to April) and wet season (May to November), with a total of three dry and two wet seasons sampled.

In addition to the transect sampling, from April of 2006 to January 2017 one of the authors continued collecting specimens of species which were not found in the transect methodology. With this we intend to present in this work a significant majority of the species richness of skippers in the study site. Also, some larvae were collected and reared in plastic bags with its host plant, to obtain additional information about early stages and biology of some species. Host plant identifications were done with the help of a botanist from the Escuela de Biología of the Universidad de Costa Rica. 

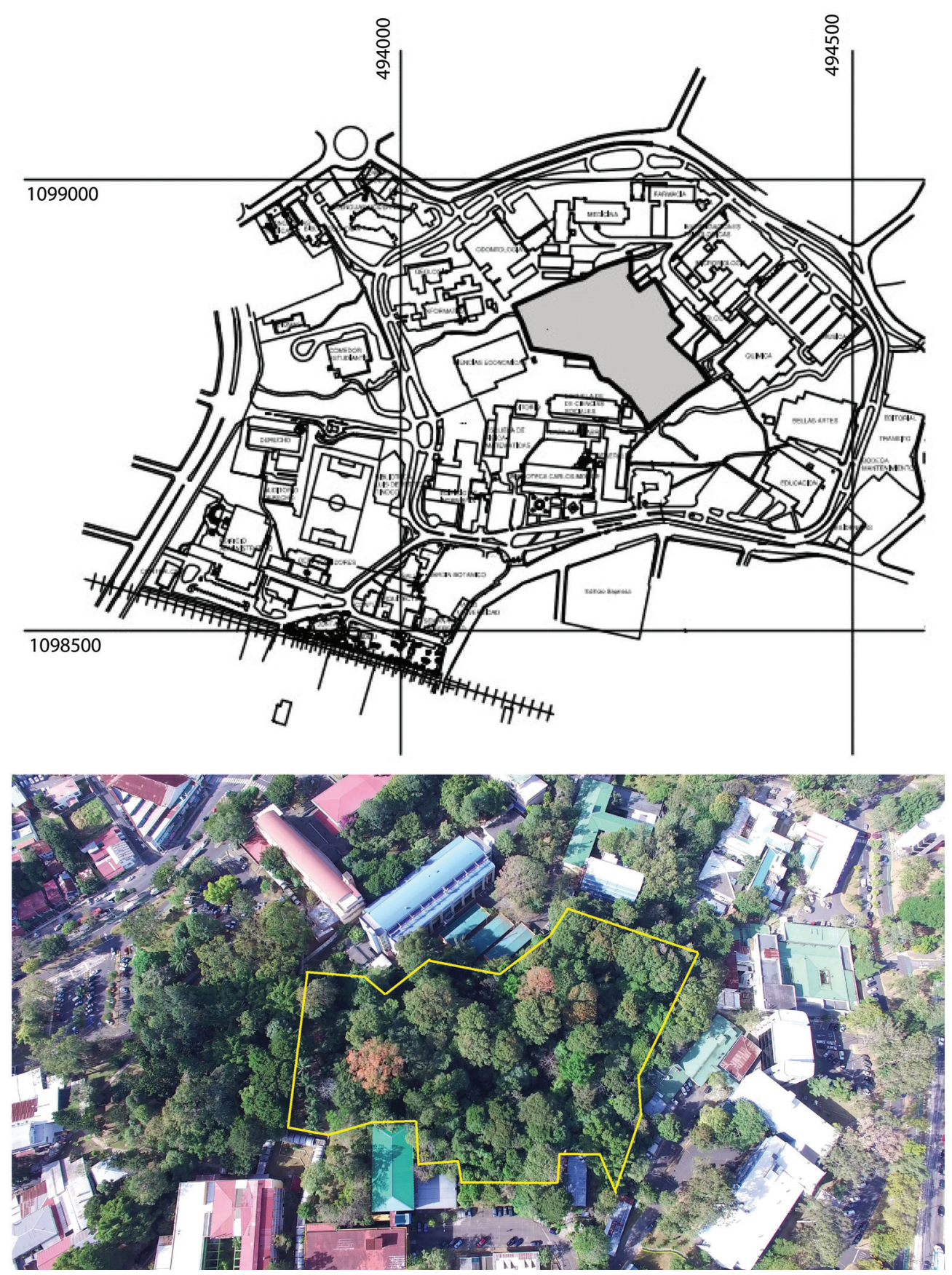

Fig. 1. a) administrative map of the Ciudad Universitaria Rodrigo Facio with the RELO (gray area). b) aerial view of the reserve enclosed in a yellow line (picture: Victor Madrigal). 


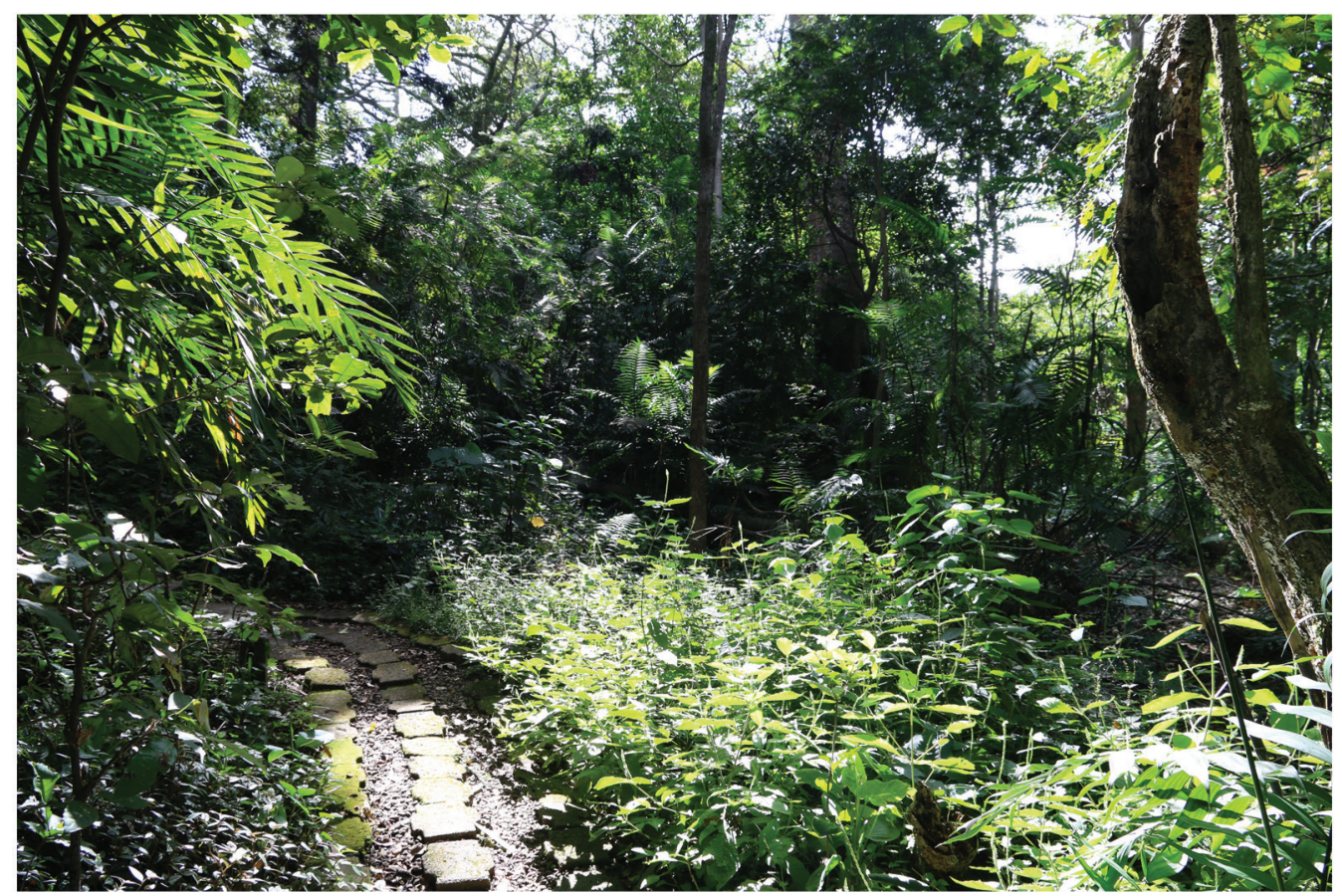

Fig. 2. Interior view of the reserve with detail of the trail used as transect (picture: Ricardo Murillo).

The butterflies were mounted, pinned for identification and deposited in the Museo de Zoología of the Escuela de Biología of the Universidad de Costa Rica. Identifications were done by comparing the specimens with the ones in the Museo Nacional de Costa Rica, Instituto Nacional de Biodiversidad (InBio) and with the help of a specialist from McGuire Center for Lepidoptera and Biodiversity. For identifying cryptic species, male genitalia dissections were done.

For the cumulative number of species and the Jacknife estimate of species abundance for 21 months, EstimateS 9.1.0 (Colwell \& Elsensohn, 2014) was used, estimating 95 $\%$ boundaries with 100 randomizations when possible for the cumulative number of species. With the Jacknife estimate $95 \%$ confidence limits were calculated. For the summary of the data, the months were analyzed according to dry and wet season. For a comparison of richness and abundance we did a g-test to evaluate if there were differences between seasons. With the use of the R package vegan (Oksanen et al., 2017) a hierarchical cluster analysis was done using the Jaccard index with the Ward's minimum variance agglomerative method. With $\mathrm{R}$ package pvclust (Susuki \& Shimodaira, 2015) the uncertainty of the clusters was achieved based on a bootstrap with 10000 iterations.

Male genitalia dissections were treated with $10 \% \mathrm{KOH}$ at boiling point, and examined with a Nikon binocular stereoscope model C-DS. The clean genitalia were then stored in vials with $75 \%$ alcohol. Genitalia drawings were done with the help of photographs taken with a binocular stereoscope with a LEICA EZ4HD camera. Adult photographs were taken with a Cannon EOS 70D camera with a macro photography lens and plates were mounted with Adobe Photoshop.

\section{RESULTS}

Taxonomy: Skipper butterflies are one of the less studied day-flying Lepidoptera 
in the Neotropics, which is probably due to their enormous diversity, small size, mostly brown coloration, and numerous cryptic species which can only be distinguished by a few small details. Also, many genera require the examination of genitalia to obtain an accurate identification. That is the case of the genus Mnasitheus which is the only one that we were not able to identify to species level for this study. Thus, the statistical analysis was done considering two morpho species differentiated by size. Another case of difficult species are those of Papias where two species were found and were only distinguishable by genitalia $(P$. dictys Fig. 3a and P. subcostulata Fig. 3b). Small individuals of Bolla can be confused with large Staphylus, and for this reason we also illustrated the male genitalia of Bolla brennus (Fig. 3c) and Staphylus ascalaphus (Fig. 3d). Finally, the male genitalia of Buzyges
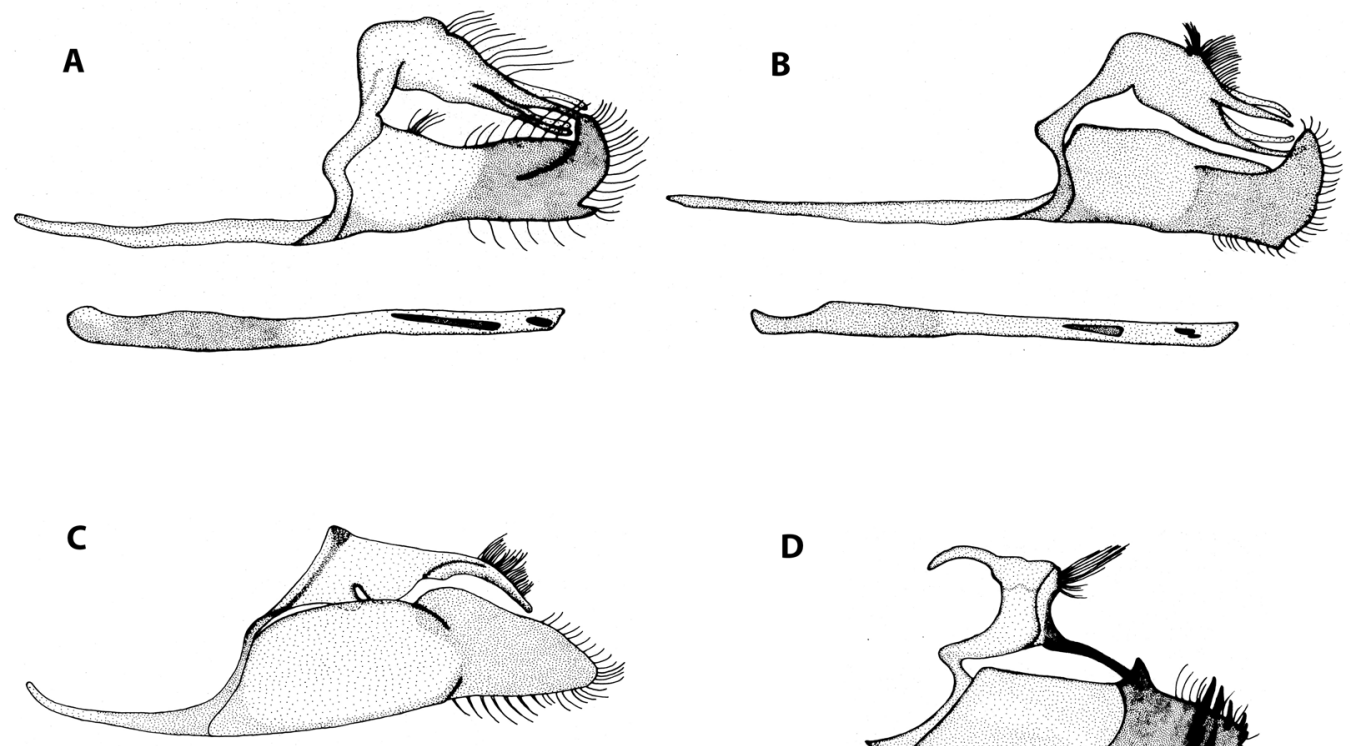

D
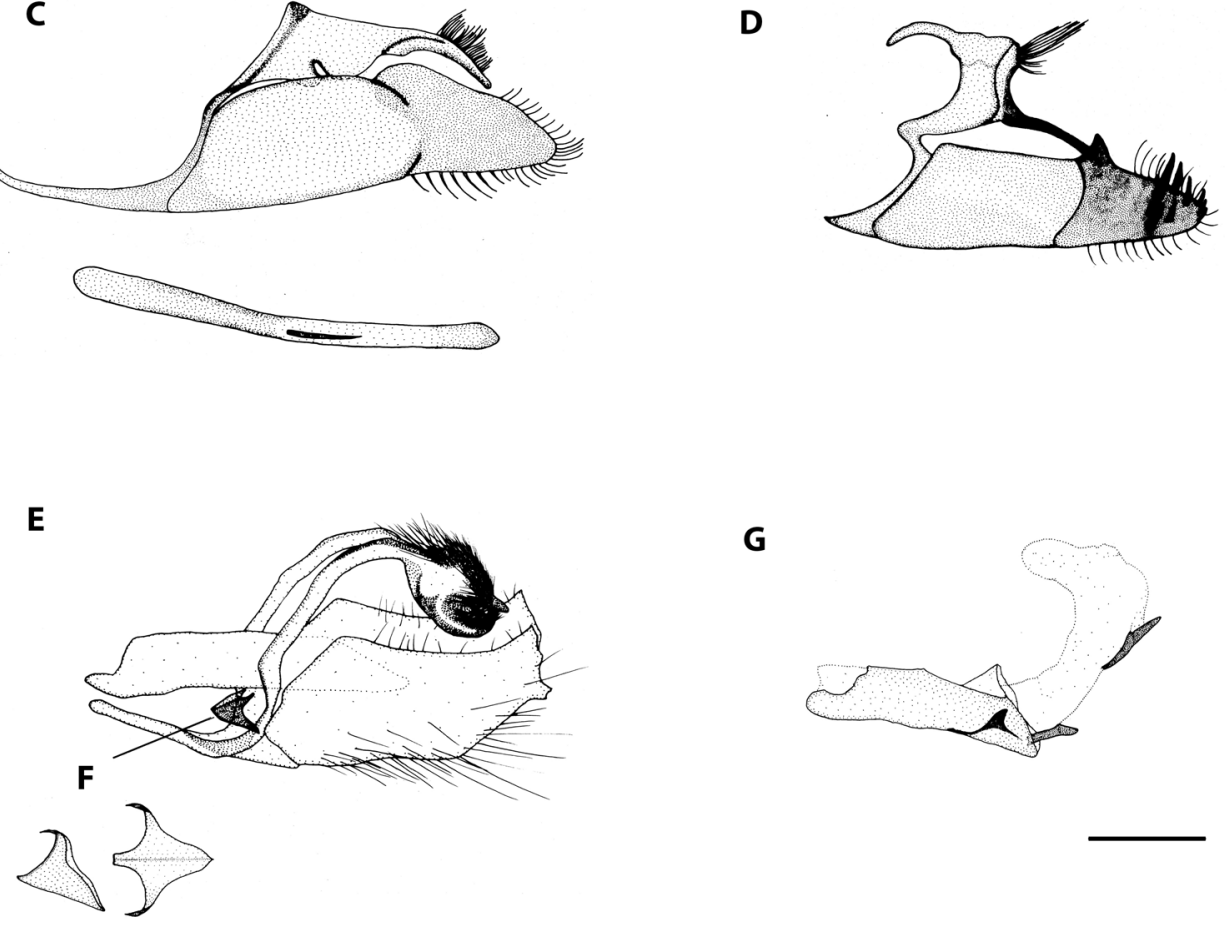

G

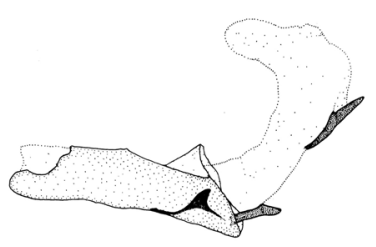

Fig. 3. Male genitalia of a) Papias dictys. b) Papias subcostulata. c) Bolla brennus. d) Staphylus ascalaphus. e) Buzyges rolla. f) juxta detail of $B$. rolla and $\mathbf{g}$ ) aedeagus with everted vesica of $B$. rolla. 
rolla (Fig. 3e) have been included because of its similarity to Poanes zabulon (Fig. 3: f and $\mathrm{g}$ shows details of its juxta and aedeagus with everted vesica, respectively).

For general species identification of Hesperiidae of the reserve, we have included an identification guide. Individuals of all the species are shown dorsally; when needed, the ventral side was also included. When species are sexually dimorphic, both sexes are illustrated with exception of Buzyges rolla for which we had no females and Dyscophellus p. phraxanor for which we had no males. Plates are arranged as follows: plate 1, Eudaminae; plate 2, Pyrginae; and plates 3-7, Hesperiinae.

Species richness and abundance: A total of 435 Hesperiidae specimens of 58 species were collected from March 2004 to January 2017 (Table 1). From those, 423 specimens of 49 species were collected as part of the 2 years transect sampling. The species collected belong to 46 genera and three subfamilies: Eudaminae with five genera and nine species, Pyrginae with eight genera and nine species, and Hesperiinae with 33 genera and 40 species.

TABLE 1

Skippers species list found in the RELO and their seasonal occurrence

\begin{tabular}{|c|c|c|}
\hline Taxa & Dry Season & Wet Season \\
\hline \multicolumn{3}{|l|}{ EUDAMINAE } \\
\hline \multicolumn{3}{|l|}{ Astraptes Hübner, 1807} \\
\hline Astraptes alardus (Stoll, 1790) & 1 & 5 \\
\hline Astraptes anaphus (Cramer, 1777) & 5 & 6 \\
\hline \multicolumn{3}{|l|}{ Dyscophellus Godman \& Salvin, 1893} \\
\hline *Dyscophellus porcius (C. Felder \& R. Felder, 1862) & - & 3 \\
\hline *Dyscophellus phraxanor phraxanor (Hewitson, 1876) & - & 1 \\
\hline \multicolumn{3}{|l|}{ Phanus Hübner, 1819} \\
\hline *Phanus marshalli (W.F. Kirby, 1880) & - & 1 \\
\hline \multicolumn{3}{|l|}{ Polythrix Watson, 1893} \\
\hline *Polythrix mexicanus H.A. Freeman, 1969 & - & 1 \\
\hline \multicolumn{3}{|l|}{ Urbanus Hübner, 1807} \\
\hline Urbanus dorantes (Stoll, 1790) & - & 2 \\
\hline Urbanus esta Evans, 1952 & 2 & - \\
\hline Urbanus teleus (Hübner, 1821) & 7 & - \\
\hline \multicolumn{3}{|l|}{ PYRGINAE } \\
\hline \multicolumn{3}{|l|}{ Achlyodes Hübner, 1819} \\
\hline Achlyodes busirus (Cramer, 1779) & 1 & - \\
\hline Achlyodes pallida (R. Felder, 1869) & 2 & - \\
\hline \multicolumn{3}{|l|}{ Atarnes Gordman \& Salvin, 1897} \\
\hline Atarnes sallei (C. Felder \& R. Felder, 1867) & 1 & - \\
\hline \multicolumn{3}{|l|}{ Bolla Mabille, 1903} \\
\hline Bolla brennus (Godman \& Salvin, 1896) & 14 & 8 \\
\hline \multicolumn{3}{|l|}{ Heliopetes Billberg, 1820} \\
\hline Heliopetes alana (Reakirt, 1868) & 10 & - \\
\hline \multicolumn{3}{|l|}{ Pyrgus Hübner, 1819} \\
\hline Pyrgus oileus (Linnaeus, 1767) & 3 & - \\
\hline \multicolumn{3}{|l|}{ Pythonides Hübner, 1819} \\
\hline Pythonides zera (Butler, 1870) & 1 & - \\
\hline \multicolumn{3}{|l|}{ Staphylus Godman \& Salvin, 1896} \\
\hline Staphylus ascalaphus (Staudinger, 1876) & - & 4 \\
\hline
\end{tabular}


TABLE 1 (Continued)

\begin{tabular}{|c|c|c|}
\hline Taxa & Dry Season & Wet Season \\
\hline \multicolumn{3}{|l|}{ Xenophanes Godman \& Salvin, 1895} \\
\hline Xenophanes tryxus (Stoll, 1780) & 6 & 2 \\
\hline \multicolumn{3}{|l|}{ HESPERIINAE } \\
\hline \multicolumn{3}{|l|}{ Ancyloxypha Felder, 1863} \\
\hline *Ancyloxypha arene (W.H. Edwards, 1871) & 1 & - \\
\hline \multicolumn{3}{|l|}{ Buzyges Godman, 1900} \\
\hline Buzyges rolla (Mabille, 1883) & 12 & 13 \\
\hline \multicolumn{3}{|l|}{ Callimormus Scudder, 1872} \\
\hline Callimormus juventus Scudder, 1872 & 8 & - \\
\hline \multicolumn{3}{|l|}{ Calpodes Hürber, 1819} \\
\hline Calpodes ethlius (Stoll, 1782) & 1 & 1 \\
\hline \multicolumn{3}{|l|}{ Cobalopsis Godman, 1900} \\
\hline Cobalopsis nero (Herrich-Schäffer, 1869) & 5 & 2 \\
\hline \multicolumn{3}{|l|}{ Conga Evans, 1955} \\
\hline Conga chydaea (Butler, 1877) & 6 & - \\
\hline \multicolumn{3}{|l|}{ Corticea Evans, 1955} \\
\hline Corticea lysias lysias (Plötz, 1883) & - & 1 \\
\hline \multicolumn{3}{|l|}{ Cymaenes Scudder, 1872} \\
\hline Cymaenes odilia trebius (Mabile, 1891) & 9 & 2 \\
\hline \multicolumn{3}{|l|}{ Cynea Evans, 1955} \\
\hline Cynea cynea (Hewitson, 1876) & 31 & 28 \\
\hline \multicolumn{3}{|l|}{ Dion Godman, 1901} \\
\hline *Dion gemmatus (Burler, 1872) & 1 & - \\
\hline \multicolumn{3}{|l|}{ Halotus Godman, 1900} \\
\hline Halotus rica (Bell, 1942) & - & 4 \\
\hline \multicolumn{3}{|l|}{ Lychnuchoides Godman, 1901} \\
\hline Lychnuchoides saptine (Godman \& Salvin, 1879) & - & 1 \\
\hline \multicolumn{3}{|l|}{ Mnasitheus Godman, 1900} \\
\hline Mnasitheus sp.1 & 1 & 1 \\
\hline Mnasitheus sp.2 & 4 & 1 \\
\hline \multicolumn{3}{|l|}{ Mucia Godman, 1900} \\
\hline Mucia zygia (Plötz, 1886) & 1 & 2 \\
\hline \multicolumn{3}{|l|}{ Naevolus Hemming, 1939, repl. name } \\
\hline Naevolus orius orius (Mabille, 1883) & 2 & 1 \\
\hline \multicolumn{3}{|l|}{ Niconiades Hübner, 1821} \\
\hline Niconiades nikko (Hayward, 1948) & 8 & 1 \\
\hline \multicolumn{3}{|l|}{ Oxynthes Godman, 1900} \\
\hline Oxynthes corusca (Herrich-Schäffer, 1869) & 5 & 1 \\
\hline \multicolumn{3}{|l|}{ Panoquina Hemming, 1934} \\
\hline Panoquina evadnes (Stoll, 1781) & - & 2 \\
\hline \multicolumn{3}{|l|}{ Papias Godman 1900} \\
\hline Papias dictys Godman 1900 & 1 & - \\
\hline Papias subcostulata (Herrich Schäffer, 1870) & 26 & 24 \\
\hline \multicolumn{3}{|l|}{ Perichares Scudder, 1872} \\
\hline Perichares deceptus (Butler \& H. Druce, 1872) & - & 1 \\
\hline Perichares lotus (Butler, 1870) & 3 & 5 \\
\hline Perichares philetas adela (Hewitson, 1867) & 1 & - \\
\hline
\end{tabular}


TABLE 1 (Continued)

\begin{tabular}{|c|c|c|}
\hline Taxa & Dry Season & Wet Season \\
\hline \multicolumn{3}{|l|}{ Poanes Scudder, 1872} \\
\hline Poanes zabulon (Boisduval \& Le Conte, [1837]) & 6 & 1 \\
\hline \multicolumn{3}{|l|}{ Polites Scudder, 1872} \\
\hline *Polites vibex vibex (Hübner, [1819]) & 1 & - \\
\hline \multicolumn{3}{|l|}{ Pompeius Evans, 1955} \\
\hline Pompeius pompeius (Latreille, [1824]) & 5 & - \\
\hline \multicolumn{3}{|l|}{ Quinta Evans, 1955} \\
\hline Quinta cannae (Herrich-Schäffer, 1869) & 3 & - \\
\hline \multicolumn{3}{|l|}{ Remella Hemming, 1939} \\
\hline Remella rita (Evans, 1955) & 14 & 4 \\
\hline \multicolumn{3}{|l|}{ Rhinton Godman, 1900} \\
\hline Rhinthon osca (Plötz, 1882) & - & 3 \\
\hline \multicolumn{3}{|l|}{ Saliana Evans, 1955} \\
\hline Saliana esperi Evans, 1955 & 10 & 7 \\
\hline \multicolumn{3}{|l|}{ Synale Mabille, 1904} \\
\hline Synale cynaxa (Hewitson, 1867) & 3 & 7 \\
\hline \multicolumn{3}{|l|}{ Synapte Mabille, 1904} \\
\hline Synapte salenus (Mabille, 1883) & 23 & 10 \\
\hline \multicolumn{3}{|l|}{ Talides Hübner, 1910} \\
\hline Talides sinois Hübner, [1819] & 1 & - \\
\hline \multicolumn{3}{|l|}{ Thespieus Godman, 1900} \\
\hline *Thespieus dalman (Latreille, [1824]) & 1 & - \\
\hline Thespieus macareus (Herrich-Schäffer, 1869) & 3 & 2 \\
\hline \multicolumn{3}{|l|}{ Thracides Hübner, 1819} \\
\hline *Thracides phidon (Cramer, 1779) & 2 & - \\
\hline \multicolumn{3}{|l|}{ Vacerra Godman, 1900} \\
\hline Vacerra caniola (Herrich-Schäffer, 1869) & 1 & - \\
\hline Vacerra egla (Hewitson, 1877) & 3 & 13 \\
\hline Vacerra lacheres Godman, 1900 & 1 & 8 \\
\hline
\end{tabular}

The species with an asterisk* indicates that those where caught out of the statistical analysis design.

The species with an asterisk * indicate those not included in the sampling design and statistical analysis. The taxonomic arrangement follows Warren, Ogawa, \& Browner (2008) with the modifications of Warren, Ogawa \& Browner (2009) and Austin \& Warren (2009).

From the 21 sampling months (9 dry and 12 rainy) over the two years a speciesaccumulation curve was calculated in order to visualize the probabilities of catching new species in the future and to evaluate the success of the sampling design (Fig. 4). From these data, and according to a Jacknife estimate of species

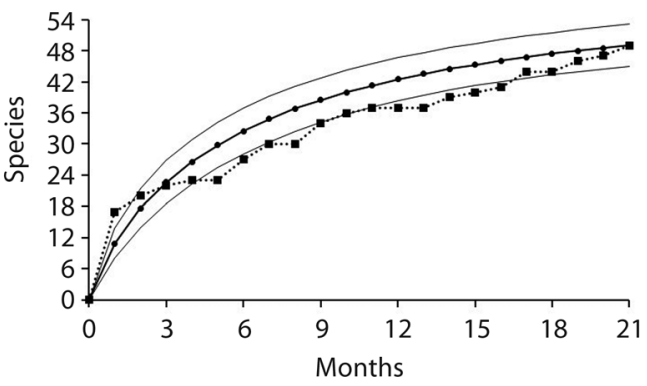

Fig. 4. Species accumulation curve obtained from 21 sampling months; - $\mathbf{-}-$ : data obtained from sampling, -•-: Jacknife estimate, - $\longrightarrow$ : upper and lower $95 \%$ confidence limits of Jacknife estimate. 

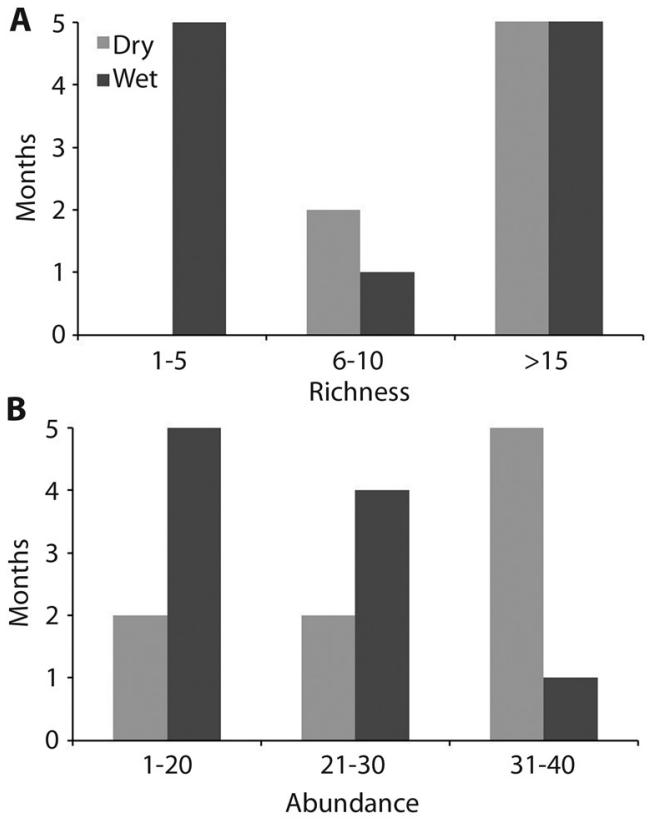

Fig. 5. a) Species richness and b) abundance of skipper butterflies by months, according to rain or dry seasons.

abundance, a total of 58.52 (51.95-65.10 95 $\%$ interval) species are expected to inhabit the reserve, which is very close to the 59 total species found after 13 years of collecting. When comparing species richness (Fig. 5a) and abundance (Fig. 5b) between dry and wet season, the analysis shows more species $(G=6.92$, d.f. $=2, \mathrm{P}=0.031)$ and greater abundance $(\mathrm{G}=$ $6.10, \mathrm{df}=2, \mathrm{P}=0.047$ ) during the dry season. In other words, there are more individuals and more species that are common during the dry months. However, during the rainy season it is normal to find either a low or high number of different species, but in low abundance. For instance, there were more rainy months when low richness and abundance were observed; only one rainy month had more than sixteen species with almost forty individuals. In contrast, four dry season months had more that sixteen species and five of them with almost forty individuals.

The cluster analysis shows that both rainy seasons are grouped in a significant way $(\mathrm{P}$ $=0.05)$. The dry seasons are also grouped

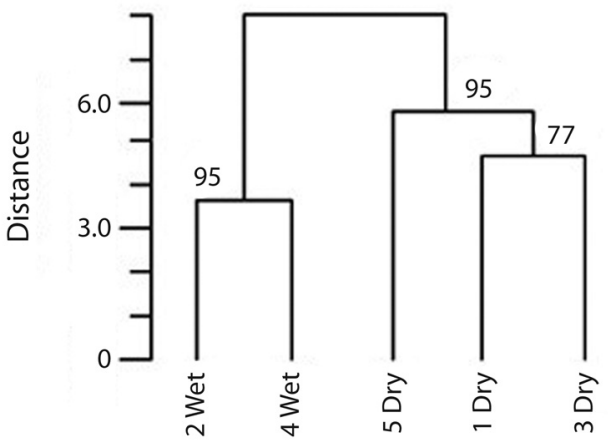

Fig. 6. Cluster tree showing distances among seasons for skipper butterflies in Reserva Ecológica Leonelo Oviedo. Using Jaccard index with Ward minimum variance junction procedure. Numbers on branches indicate the approximately unbiased (AU) significance level as percentages $(\mathrm{P}=1-\mathrm{AU} / 100)$.

significantly $(\mathrm{P}=0.05)$; however dry periods 1 and 3 are not $(\mathrm{P}=0.23)$ (Fig. 6).

Natural history: During the 13 years collecting period, there were three species that were never seen as adults in their habitat. Instead, they were obtained by collecting larvae from their host plants: Halotus rica on Guadua angustifolia (Poaceae), Thracides phidon and Talides sinois on Heliconia tortuosa (Heliconiaceae). Other species were captured in adult and larval stage: Astraptes alardus on Erythrina poeppigiana (Fabaceae), Atarnes sallei on Annona glabra (Annonaceae), Pythonides zera on Persea americana and Cinnamomun triplinerve (Lauraceae), Achlyodes pallida on Citrus spp. (Rutaceae), Synale cynaxa on Chamaedorea costaricana (Arecaceae), Panoquina evadnes on Dypsis lutescens (Arecaceae), Oxynthes corusca, Cynea cynea and Perichares lotus on Guadua angustifolia (Poaceae).

None of the skipper species found in the RELO was very abundant. Some species can be easily seen any time of the year when there is sunshine, for example Cynea cynea, Papias subcostulata, Heliopetes alana, Buzyges rolla, Synapte salenus, Astraptes anaphus, Saliana esperi and Bolla brennus. These species are often seen nectaring from flowers in the open 
areas such as the sides of creeks or light gaps produced by fallen trees. Among the most visited flower plants by the skippers in the reserve are Melanthera nivea (Asteraceae), Lantana urticifolia and Stachytarpheta mutabilis (Verbenaceae), and Alternanthera pubiflora (Amaranthaceae). 25 species occur throughout the year, 21 species are exclusive of the dry season and 12 of the wet season. For example, Callimormus juventus, Conga chydaea and Quinta cannae were caught only during the dry season, whereas Panoquina evadnes, Rhinthon osca and Staphylus ascalaphus were collected only during the rainy season.

\section{DISCUSSION}

In general terms, the skipper species of the reserve are not difficult to identify. The majority can be identified to species level when seen in the wild. A few need to be collected for hand examination (Perichares spp., Mucia zygia, Vacerra spp. Pompeius pompeius Polites v. vibex, Poanes zabulon, Buzyges rolla, Cymaenes odilia trebius and Cobalopsis nero), and only a few need to be killed for genitalic analysis (Papias dictys, Papias subcostulata, Mnasitheus spp., Bolla brennus and Staphylus ascalaphus).

Mnasitheus were difficult to identify. After genitalic examination there seem to be three or four species in the RELO, all of them are similar in size and color pattern. The genitalia dissected from the individuals collected do not resemble the illustrations of Godman \& Salvin (1887-1901) for Mnasitheus cephoides, M. chrysophrys or M. simplicissima. Also, the illustration provided by Hayward (1941) in the description of Mnasitheus cephoides show only some parts of the male genitalia because he did not draw the whole genitalia. Finally, Mnasitheus nitra genitalia were illustrated from northern Guatemala (Austin, 1997), but do not resemble the ones obtained from this study. Due to the small number of genitalia illustrations available in the literature, it is important to include them in future publications of Hesperiidae. In the case of the RELO, more studies must be conducted in order to determine if there are new Mnasitheus species and genitalia illustrations will help to advance studies of Hesperiidae since species identifications will be more accessible.

It is remarkable that in the RELO, the species richness is higher than expected when compared with similar studies. For instance Vega \& Gloor (2001) and Vega (2012) reported 65 species in one collecting year in El Rodeo; which is a protected, well conserved area of the same life zone but, of approximately 2100 ha. It was expected that El Rodeo would have many more species since Shreeve \& Mason (1980) suggest that the size of the forest area is positively related to the number of species. Nonetheless, as has been shown in other studies, small urban vegetation patches can sometimes hold more diversity than larger, better conserved forests (Owen, 1971). The similarity of the species richness among these two areas probably reflects collecting effort since one might expect more species in El Rodeo but, our study was conducted for more years and focused only on Hesperiidae. The species list of Vega \& Gloor, (2001) and Vega (2012) was based on only two years of collecting and included all butterfly families.

More comparable is the study by Nishida et al. (2009). They registered 65 skipper species for the RELO, the same study site as was used in our research. If eight species which were identified only to genus are removed from their list there are only 57 species, a very similar number to what we report here. They obtained 23 species (40\% of their total) that we did not record while we recorded 25 species (42\% of our total) that they did not record. As result, $34(59 \%)$ species are reported by the two studies. Nishida et al. (2009) obtained their data from 1997 to 2007 and included data from specimens collected by entomology students of the University of Costa Rica, while our study was conducted for 13 years, from 2004 to 2017, and only included specimens collected by the authors.

A possible explanation for the difference in the species composition between these two 
studies, is that close to the $40 \%$ of the skipper species of the RELO are actually non-resident in the area. These 23-25 species come to the reserve as part of a population from a larger area and they move across the vegetation along the rivers or just fly from one forest patch to another. Something similar has been shown by Kronforst \& Fleming (2001) in the case of Heliconius charitonia (Nymphalidae) where there is gene flow between separate populations, demonstrating that individuals can actually move through cities.

It is possible that Anthopus, Epictetus, Poanes inimica, Zenis jebus, Noctuana lactifera and Autochton vectilucis reported by Nishida et al. (2009), as well as Polythrix mexicanus, Phanus marshalli, Achlyodes busirus, Lychnuchoides saptine and Dion gemmatus, do not actually have a population in the reserve, but instead were caught as they were passing from one side of the city to another, especially since Hesperiidae is a group known for fast and powerful flight (Emmel \& Leck, 1970; Scoble, 1992; Murillo-Hiller, 2008). The species-accumulation curve presented in this work (Fig. 4) is evidence that no more than 60 species of skippers are expected to be found in the RELO, as is also supported by our jackknife estimate.

Because the RELO is embedded in an urban matrix, the dispersal of certain organisms may coincide with that proposed in the island equilibrium model proposed by MacArthur \& Wilson (1967), where the number of species of an island is in a dynamic equilibrium between immigration and extinction. Moreover, the connectivity of the RELO with other green areas is maintained through the Negritos Creek, increasing the effective area of the forest (Di Stefano et al., 1996). That is to say, the Negritos Creek offers connectivity with nearby wooded areas by acting as a narrow biological corridor (Nishida et al., 2009). This could allow for the migration of some species that are not habitual residents of RELO, thus forming a population made up of local species as well as external species. Because of this, the two ha. of protected forest in the RELO is more comparable to a larger conserved forest than to an urban reserve. Urban reserves are characterized by high abundance of some species and a low quantity of host specialist species (RamírezRestrepo \& MacGregor-Fors, 2017), opposite to the RELO where there are many species and none of them abundant.

Conditions such as high levels of relative humidity and a variety of flowering plants that serve as a food resources for butterflies (Moyers-Arévalo \& Cano-Santana, 2009) could facilitate the return of rare species during some years. During the dry season precipitation levels are low, so that mechanical damage to butterflies is reduced (Emmel \& Leck, 1970). Plant density varies markedly between seasons (Nishida et al., 2009), being most exuberant during the wet season. This would benefit the displacement of skippers, resulting in greater connectivity and thus a greater flow of species, which explains the increase of rare species in the rainy season. With respect to the mechanical damage that rain can cause to the butterflies, it can be argued that the extra vegetation cover provides shelter thereby mitigating the adverse effects of rain.

The above hypothesis is also supported by the fact that abundance and richness of skippers from the dry season and the rainy season are positively correlated (Fig. 6). These populations seem to be intermittent, probably because their small population size, which makes them vulnerable to local extinctions due to stochastic processes (Lande, 1988).

According to DeVries (1987), the RELO is located in an ecotone between the Guanacaste dry forest and the wetter mid-elevation forests of Talamanca. There is virtually no rain from December to April and intense rains from May to November (Coen, 1983; DeVries, 1987; Bolaños et al., 2005). Rainfall is a variable which directly affects butterfly populations (Emmel \& Leck, 1970; DeVries, 1987; Torres, Osorio-Beristain, Mariano, \& Legal, 2009), where rain season seems to negatively affect the abundance but not the species richness; on the other hand, the dry season propitiates the increasing of abundance and richness of Hesperiidae in the RELO as can be seen in Fig. 5. Our 
data suggest that during the dry months there are more probabilities of observing more individuals of more species than during the rainy months. This contradicts the observations of DeVries $(1983,1987)$ who states that, in general terms, butterfly diversity in the Costa Rican Pacific slope increases with rainfall. In a study conducted with 92 butterfly species in Panama, it has been found that butterfly abundance and diversity are affected differently by rainfall, according to habitat characteristics (Emmel \& Leck, 1970). They found that in open areas abundance and diversity decreased during the dry season, but increased during the rainy season. On the other hand, diversity in forest areas increased in the dry season. The explanation for this is that during the dry season many species from open areas and clearings move to the forest to obtain protection in the cooler and more humid understory. The RELO is a habitat almost completely composed of tall trees with a well differentiated understory, while light gaps are rarely produced and are of small size. Longterm butterfly phenology studies (DeVries \& Walla, 2001; Valtonen et al., 2013) have found that butterfly abundance and richness increase in the rainy season, and others (Emmel \& Leck, 1970; Valtonen et al., 2013) have argued that low numbers of individuals and species collected during the rainy season might be due to fewer hours of activity during rainy days.

The exuberant vegetation in the rainy season could lead to the entry of species into the reserve that can only do so due to the increase in connectivity. This means that the composition of species entering the forest in the dry season shows differences with respect to the composition of species that enter during the wet season, because during the dry season the dispersal of some species may be limited. This could explain why the diversity of skippers observed in the different dry seasons is similar to one another, as seen in the cluster analysis (Fig. 6) and the same is true for the wet season. Throughout the year, variation in the occurrence of some species of butterflies may occur due to the way they respond to the seasonal variation of the environment (Scott \& Epstein, 1987).
This could also be linked to several vegetative factors, such as the availability of resources like flowers, host plants, refuges or specific behavior; as Dyscophellus p. phraxanor, Dyscophellus porcius and Thracides phidon that are infrequently collected as adults. D. $p$. phraxanor and D. porcius have only been collected at surrounding lights at night. It is known that some Costa Rican skippers fly at night, as is the case of Calaenorrhinus fritzgaertneri (DeVries, Schull, \& Greig, 1987). According to Austin (2008) Dyscophellus is attracted to lights at night and is seldom collected during the day. For this reason there were very few specimens of $D$. $p$. phraxanor and $D$. porcius collected from the RELO. On the other hand, T. phidon have only been obtained by rearing larvae found on Heliconia tortuosa. A possible explanation for the absence of adults but regular appearance of larvae, might be that they fly in the canopy, as occurs in many neotropical skippers (Burns \& Janzen, 2001).

Species lists of other forest fragments and gardens around Montes de Oca and San José are important for understanding the biodiversity in the city. Long-term comparisons between sites will be useful for directing conservation efforts. Hesperiidae, being one of the most diverse Lepidoptera families, is a good candidate for describing urban diversity since are taxonomically well known and are sensitive to human disturbances (Ramírez-Restrepo \& MacGregor-Fors, 2017).

Ethical statement: authors declare that they all agree with this publication and made significant contributions; that there is no conflict of interest of any kind; and that we followed all pertinent ethical and legal procedures and requirements. All financial sources are fully and clearly stated in the acknowledgements section. A signed document has been filed in the journal archives.

\section{ACKNOWLEDGMENTS}

We would like to thank Paul Hanson for critically reviewing and important comments 
on the manuscript. Also, to Andy Warren for helping to identify many of the skippers species of this work and Carlos Morales for plants identification. Finally, to Eduardo Chacón for his help and important comments on the statistical analysis.

\section{RESUMEN}

Las mariposas hespéridas (Lepidoptera: Hesperiidae) de la Reserva Ecológica Leonelo Oviedo, San José, Costa Rica. Con aproximadamente 486 especies, Hesperiidae es una de las familias más diversas de mariposas de Costa Rica. A pesar de eso, en pocas listas de especies locales son incluidas. En este trabajo, presentamos información sobre la estacionalidad, abundancia e historia natural de los hespéridos de la Reserva Ecológica Leonelo Oviedo. Ésta reserva se encuentra dentro de una matriz urbanizada y por un período de dos años se realizaron muestreos mensuales a lo largo de un sendero de $270 \mathrm{~m}$ que la atraviesa. Las recolectas se llevaron a cabo desde las 08:00 hasta las 12:00, atrapando todos los individuos encontrados a cada lado del sendero a una distancia de hasta $5 \mathrm{~m}$. Para representar mejor la riqueza de especies, se siguió recolectando individuos de manera aleatoria por más de diez años posteriores al muestreo inicial. Consecuentemente, estos individuos no fueron incluidos en el análisis estadístico realizado. Se tomaron fotografías de todas las especies obtenidas en total, para proporcionar una guía de identificación de especies. Ademas, para las especies crípticas se realizaron disecciones e ilustraciones de los genitales masculinos. Para el análisis de diversidad se utilizó el índice de Shannon con logaritmo en base dos y analizando los datos por separado de las estación lluviosa y seca. Para la comparación de riqueza y abundancia se realizó una prueba $\mathrm{G}$ y se obtuvo que hay mayor diversidad y abundancia durante la estación seca. Se utilizó el paquete vegan $\mathrm{R}$ para un análisis de conglomerados de Jaccard con un indice Ward de mínima varianza. Con el Paquete R pvclust la incertidumbre de los conglomerados se realizó con un bootstrap de 10000 interacciones. 423 individuos de 49 especies fueron incluidas en el análisis estadístico, de un total de 435 individuos de 58 especies tratadas en este trabajo. Con el análisis de conglomerados fue posible determinar que la diversidad de Hesperiidae en las dos estaciones lluviosas analizadas se agrupan significativamente $(P=0.05)$. Lo mismo que sucede con las estaciones secas $(\mathrm{P}=0.05)$. La Reserva presenta conectividad con otras áreas boscosas a través de una quebrada. Durante la estación lluviosa, el crecimiento vegetativo aumenta el paso de individuos lo que puede propiciar la llegada de nuevas especies que no necesariamente son residentes permanentes de la Reserva y establecerse en pequeñas poblaciones que incrementan la diversidad y abundancia temporalmente, Lo anterior, mas las variaciones estacionales en la disponibilidad de recursos explican la similitud de la composición de especies entre cada una de las estaciones.

Palabras clave: biodiversidad $\beta$; conservación; riqueza de especies; reserva biológica urbana; bioindicadores de calidad de hábitat.

\section{REFERENCES}

Austin, G. T. (1997). Notes on Hesperiidae in northern Guatemala, with descriptions of new taxa. Journal of the Lepidoterists' Society, 51(4), 316-332.

Austin, G. T. (2008). Hesperiidae of Rondônia, Brazil: Taxonomic comments on 'night' skippers, with descriptions of new genera and species (Lepidoptera: Eudaminae). Insecta Mundi, 29, 1-36.

Austin, G. T., \& Warren, A. (2009). New looks at and for Onespa, Buzyges, and Librita (Lepidoptera: Hesperiidae: Hesperiinae), with new combinations and descriptions of a new genus and six new species. Insecta Mundi, 89, 1-55.

Bolaños, R., Watson, V., \& Tosi, J. (2005). Mapa ecológico de Costa Rica (zonas de vida) según el sistema de clasificación de zonas de vida del mundo de L. R. Holdridge, escala 1:750 000. San José, Costa Rica: Centro Científico Tropical.

Burns, J. M., \& Janzen, D. H. (2001). Biodiversity of Pyrrhopyeine skipper butterflies (Hesperiidae) in the Area de Conservacion Guanacaste, Costa Rica. Journal of the Lepidopterists' Society, 55(1), 15-43.

Chacón, I., \& Montero, J. (2007). Mariposas de Costa Rica. Heredia, Costa Rica: Editorial INBio.

Coen, E. (1983). Climate. In D. H. Janzen (Ed.), Historia Natural de Costa Rica (pp. 666-690). San José, Costa Rica: Editorial de la Universidad de Costa Rica.

Colwell, R. K., \& Elsensohn, J. E. (2014). EstimateS turns 20: statistical estimation of species richness and shared species from samples, with non-parametric extrapolation. Ecography, 37. 609-613.

DeVries, P. J. (1983). Lista de mariposas. In D. H. Janzen (Ed.), Historia Natural de Costa Rica (pp. 666-690). San José, Costa Rica: Editorial de la Universidad de Costa Rica.

DeVries, P.J. (1987). The Butterflies of Costa Rica and their Natural History. New Jersey: Princeton University.

DeVries, P.J., Schull, J., \& Greig, N. (1987). Synchronous nocturnal activity and gregarious roosting in the neotropical skipper butterfly Calaenorrhinus fritzgaertneri (Lepidoptera: Hesperiidae). Zoological Journal of the Linnean Society, 89, 89-103. 
DeVries, J.P., \& Walla, T. (2001). Species diversity and community structure in neotropical fruit-feeding butterflies. Biological Journal of the Linnean Society, 74, 1-15.

DiStefano, J.F., Nielsen, V., Hoomans, J., \& Fournier, L.A. (1996). Regeneración de la vegetación arbórea en una pequeña reserva forestal urbana del nivel premontano húmedo, Costa Rica. Revista de Biología Tropical, 44(2), 575-580.

Emmel, T.C., \& Leck, C.F. (1970). Seasonal changes in organization of tropical rain forest butterfly populations in Panama. Journal of Research on the Lepidoptera, 8(4), 133-152.

Fulton, M. (1996). A list of Lepidoptera collected in Costa Rica. Revista de Biología Tropical, 14(2), 287-292.

Godman, F.D., \& Salvin, O. (1887-1901). Biologia Centrali-Americana. Insecta. Lepidoptera-Rhopalocera. London: Dulau \& Co., Bernard Quaritch.

Hayward, K.J. (1941). Two new neotropical Hesperiidae. Revista Chilena de Historia Natural, 45(1), 62-63.

Keer, J. T., Sugar, A., \& Packer, L. (2000). Indicator taxa, rapid biodiversity assessment, and nestedness in an endangered ecosystem. Conservation Biology, 14(6), 1726-1734.

Kronforst, M.R., \& Fleming, T.H. (2001). Lack of genetic differentiation among widely sapaced subpopulations of a butterfly with home rangebehaviour. Heredity, $86,243-250$.

Lande, R. (1988). Genetics and demography in biological conservation. Science, 241 (4872), 1455-1460.

MacArthur, R.H., \& Wilson, E.O. (1967). The Theory of Island Biogeography. New Jersey, USA: Princeton University Press.

Moyers-Arévalo, L., \& Cano-Santana, Z. (2009). Fenología de la comunidad de mariposas diurnas y su relación con la fenología floral de las plantas y otros factores ambientales. In A. Lot \& Z. Cano-Santana (Eds.), Biodiversidad del Pedregal de San Ángel (pp. 411-419). D.F. México: UNAM, Reserva Ecológica del Pedregal de San Ángel y Coordinación de la Investigación Científica.

Murillo-Hiller, L. R. (2008). Clave dicotómica para la identificación de las familias de mariposas (Rhopalocera) pertenecientes a las superfamilias Papilionoidea y Hesperioidea. Métodos en Ecología y Sistemática, $3(2), 6-11$.

Nishida, K., Nakamura, I., \& Morales, C. O. (2009). Plants and butterflies of a small urban preserve in the Central Valley of Costa Rica. Revista de Biologia Tropical, 57(1), 31-67.
Oksanen, J., Blanchet, F.G., Friendly, M., Kindt, R., Legendre, P., McGlinn, D., ... Wagner, H. (2017). vegan: Community Ecology Package. Retrieved from https:// github.com/vegandevs/vegan

Owen, D. F. (1971). Species diversity in butterflies in a tropical garden. Biological Conservation, 3, 191-198.

Pearson, D. (1994). Selecting indicator taxa for the quantitative assessment of biodiversity. Philosophical Transactions of the Royal Society of London. Series B, Biological Sciences, 354(1311), 75-79.

Pollard, E. (1997). A method for assessing changes in the abundance of butterflies. Biological Conservation, 12(2), 115-134

Ramírez-Restrepo, L., \& MacGregor-Fors, I. (2017). Butterflies in the city: a review

of urban diurnal Lepidoptera. Urban Ecosystems, 20, 171-182.

Sánchez, J., Duran, F., \& Vega, G. (2008). Diversidad de Plantas, Mamíferos y Mariposas en los Cerros de La Carpintera, Costa Rica. Informe Interno de Proyecto. Departamento de Historia Natural. Museo Nacional de Costa Rica. San José, Costa Rica: Ministerio de Cultura y Juventud.

Scoble, M. J. (1992). The Lepidoptera: Form, Function, and Diversity. Oxford University Press. New York.

Scott J. A., \& Epstein, M.E. (1987). Factors affecting phenology in a temperate insect community. American Midland Naturalist, 117(1), 103-118.

Shreeve T.G., \& Mason, C.F. (1980). The number of butterfly species. Oecologia, 45, 414-418.

Suzuki, R., \& Shimodaira, H. (2015). Pvclust: an R package for assessing the uncertainty in hierarchical clustering. Retrieved from http://stat.sys.i.kyoto-u. ac.jp/prog/pvclust/.

Torres, C., Osorio-Beristain M. Mariano, N., \& Legal, L. (2009). Sex-dependent seasonal feeding activity variations among two species of Nymphalidae (Lepidoptera) in the Mexican tropical dry forest. Annales de la Société Entomologique de France, 45(3), 265-274.

Valtonen, A., Molleman, F., Chapman, C. A., Carey, J.R., Ayres, M. P., \&. Roininen, H. (2013). Tropical phenology: bi-annual rhythms and interannual variation in an Afrotropical butterfly assemblage. Ecosphere, 4(3), 36. DOI: 10.1890/ES12-00338.1

Vega, G. (2006). Diversidad de mariposas diurnas (Lepdiotera: Rhopalocera) en los Cerros de Escazú, Costa Rica. Brenesia, 65, 43-53.

Vega, G. (2012). Mariposas diurnas de El Rodeo: diversidad y composición. Brenesia, 77, 271-296. 
Vega, G., \& Gloor, P. (2001). Lista preliminar de mariposas diurnas (Hesperioidea: Papilionoidea) de la Zona Protectora El Rodeo, Ciudad Colón, Costa Rica. Brenesia, 55/56, 101-122.

Warren, A., Ogawa, J. R., \& Browner, A. V. Z. (2008). Phylogenetic relationships of subfamilies and circumscription of tribes in the family Hesperiidae
(Lepidoptera: Hesperioidea). Cladistics, 24(5), 642-676.

Warren, A., Ogawa, J. R., \& Browner, A. V. Z. (2009). Revised classification of the family Hesperiidae (Lepidoptera: Hesperioidea) based on combined molecular and morphological data. Systematic Entomology, 34(3), 467-523.

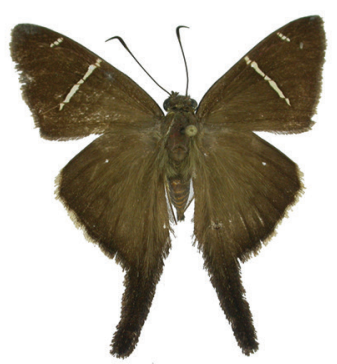

1
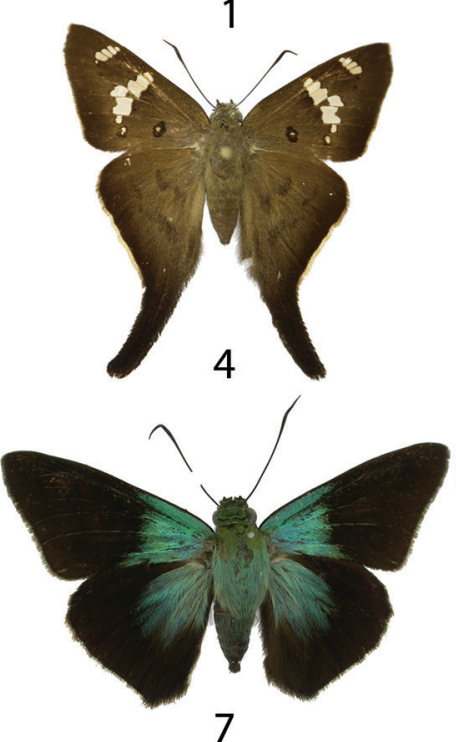

7

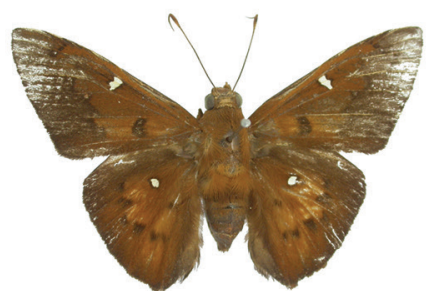

10

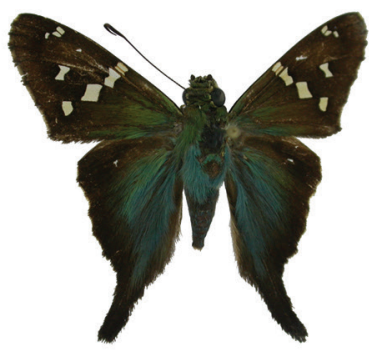

2

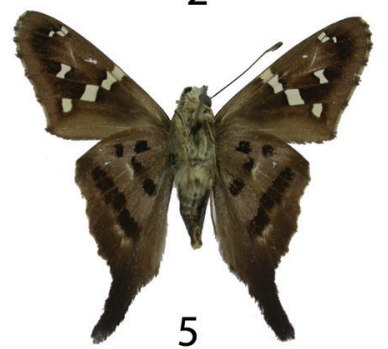

5

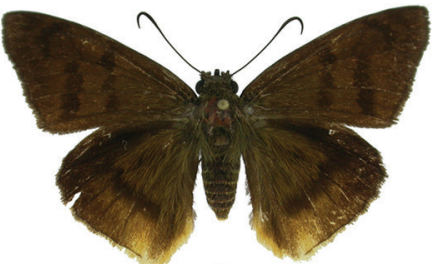

8

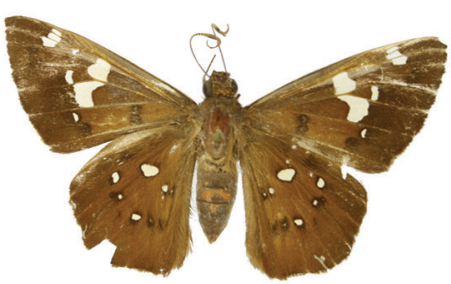

11

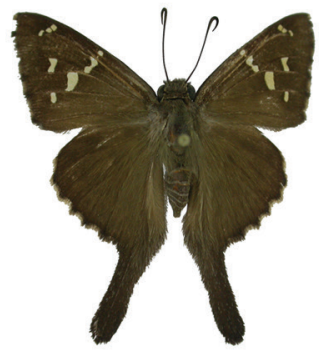

3
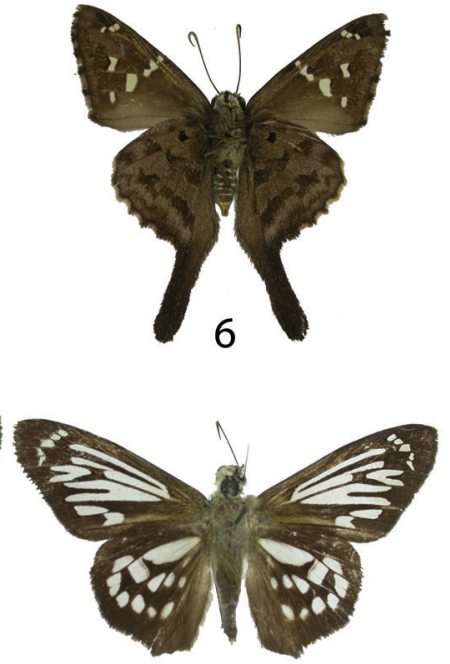

9

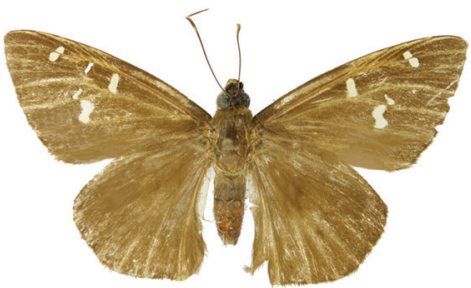

12

Plate 1. Eudaminae: 1: Urbanus teleus (d), 2: Urbanus esta (d), 3: Urbanus dorantes (d), 4: Polythrix mexicanus (d), 5: Urbanus esta (v), 6: Urbanus dorantes (v), 7: Astraptes alardus (d), 8: Astraptes anaphus (d), 9: Phanus marshalli (d), 10: Dyscophellus porcius (ふd), 11: Dyscophellus porcius (d), 12: Dyscophellus p. phraxanor ( $+\mathrm{d})$. 

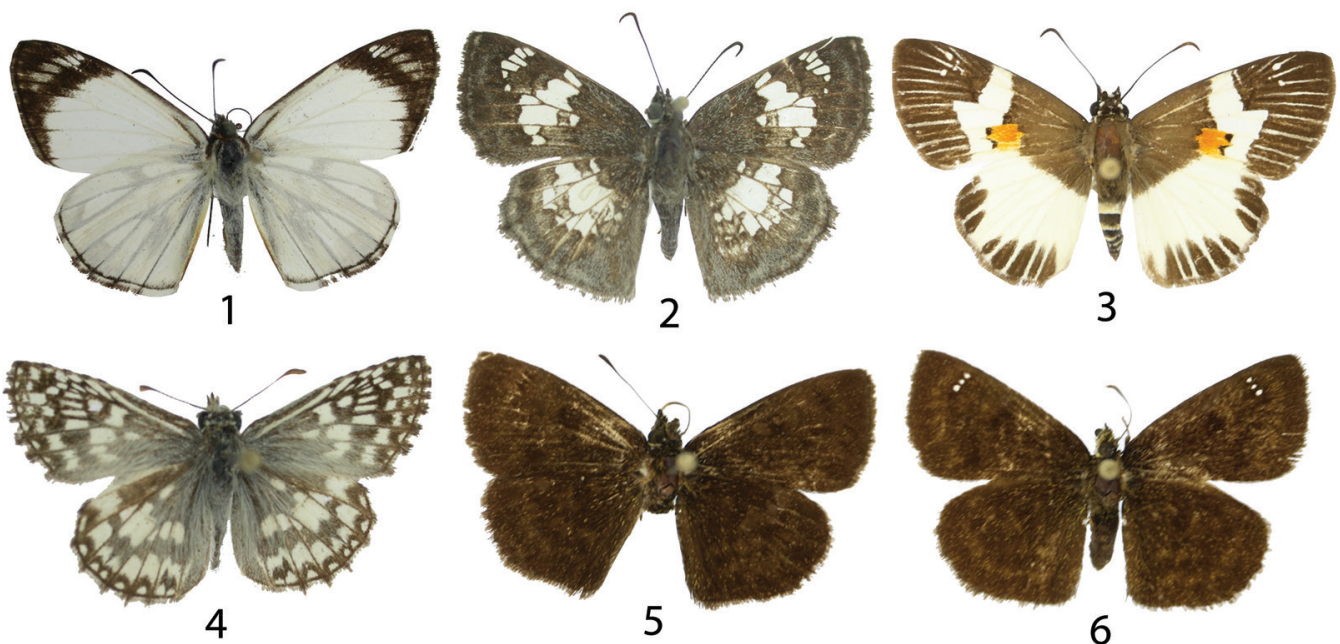

6

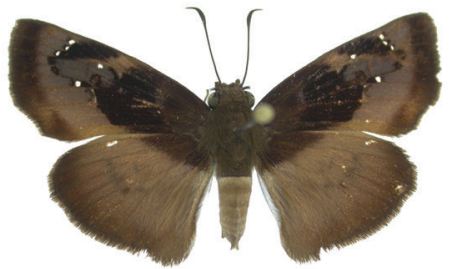

7

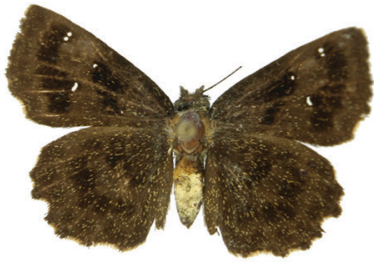

8

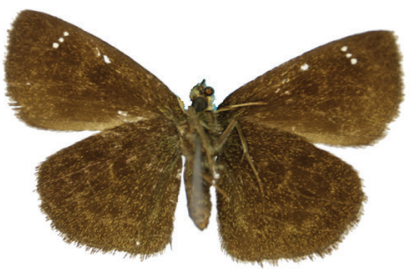

9

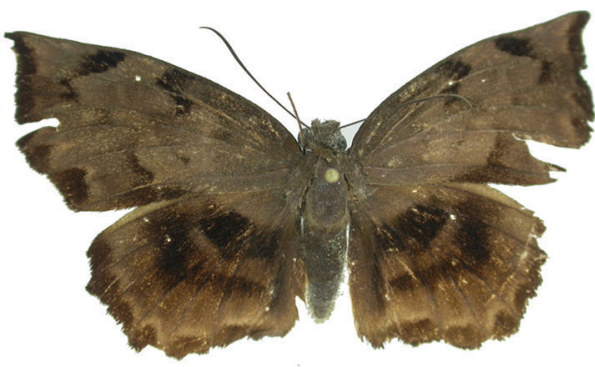

10

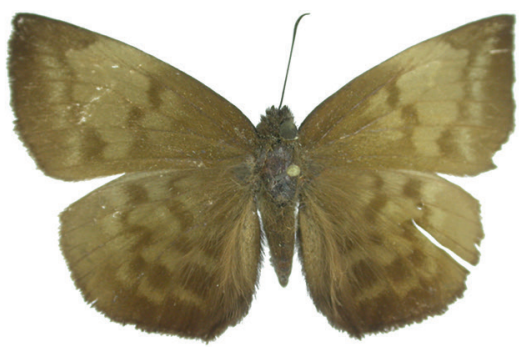

11

Plate 2. Pyrginae: 1: Heliopetes alana (d), 2: Xenophanes tryxus (d), 3: Atarnes sallei (d), 4: Pyrgus oileus (d), 5: Bolla

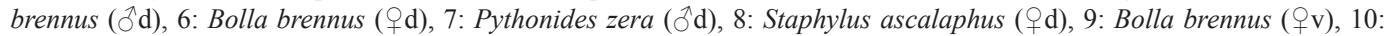
Achlyodes busirus (d), 11: Achlyodes pallida (d). 


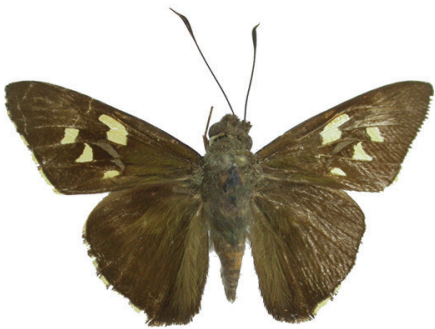

1

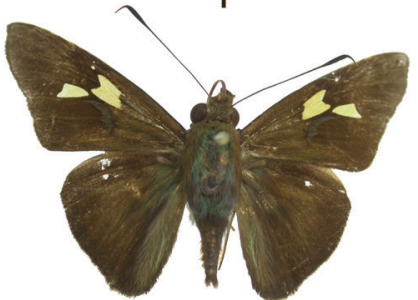

4
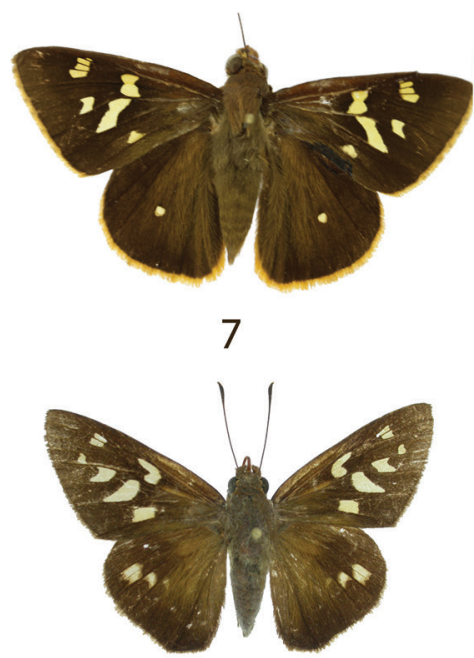

10
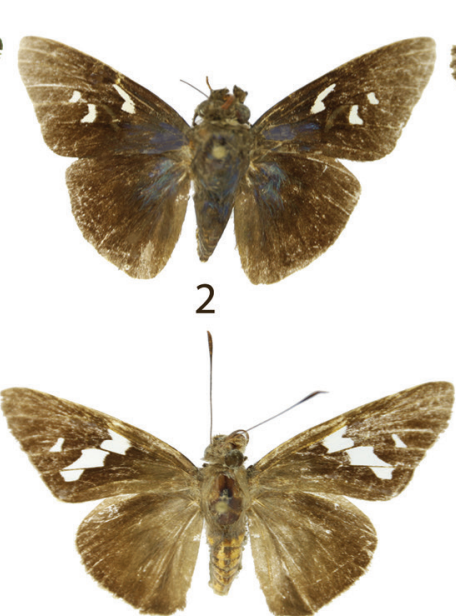

5
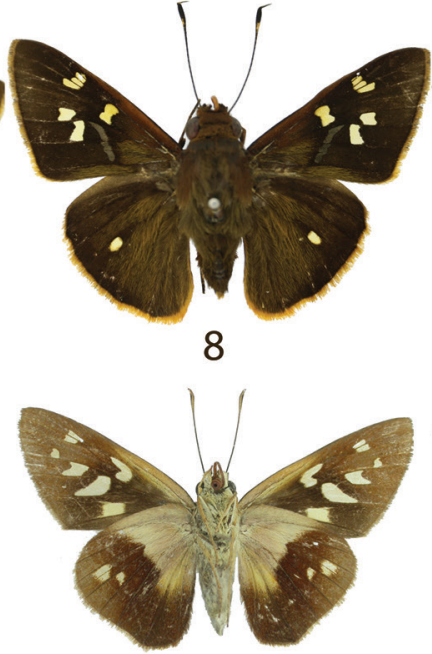

11

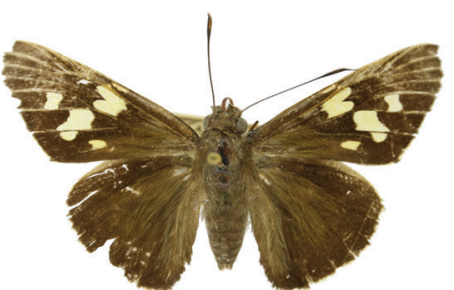

3

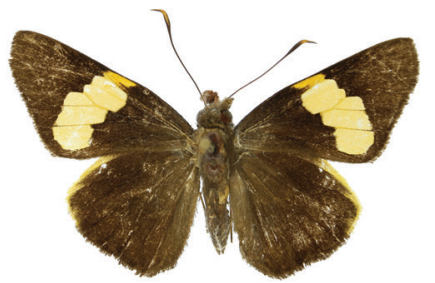

6
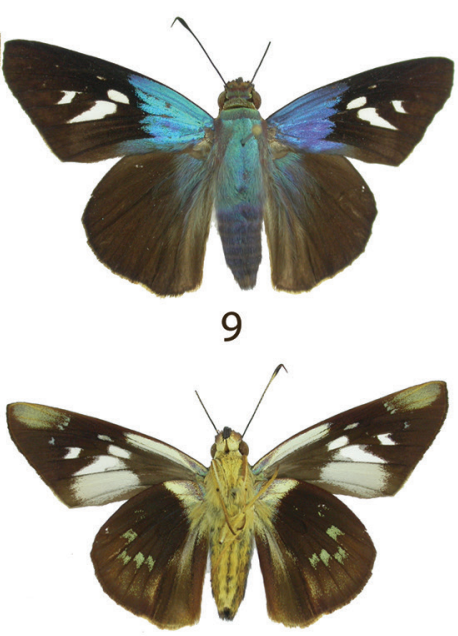

12

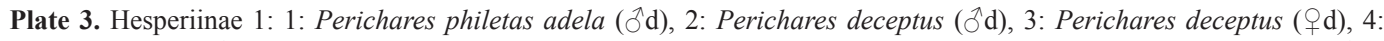

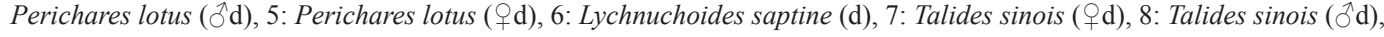
9: Thracides phidon (d), 10: Saliana esperi (d), 11: Saliana esperi (v), 12: Thracides phidon (v). 

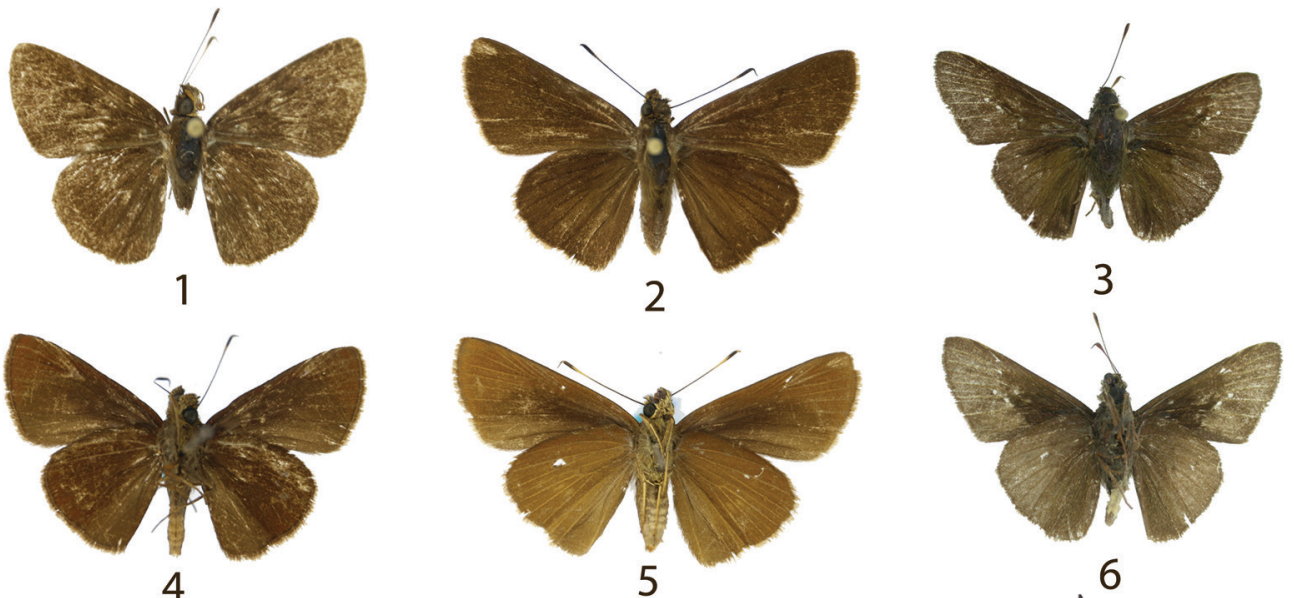

4
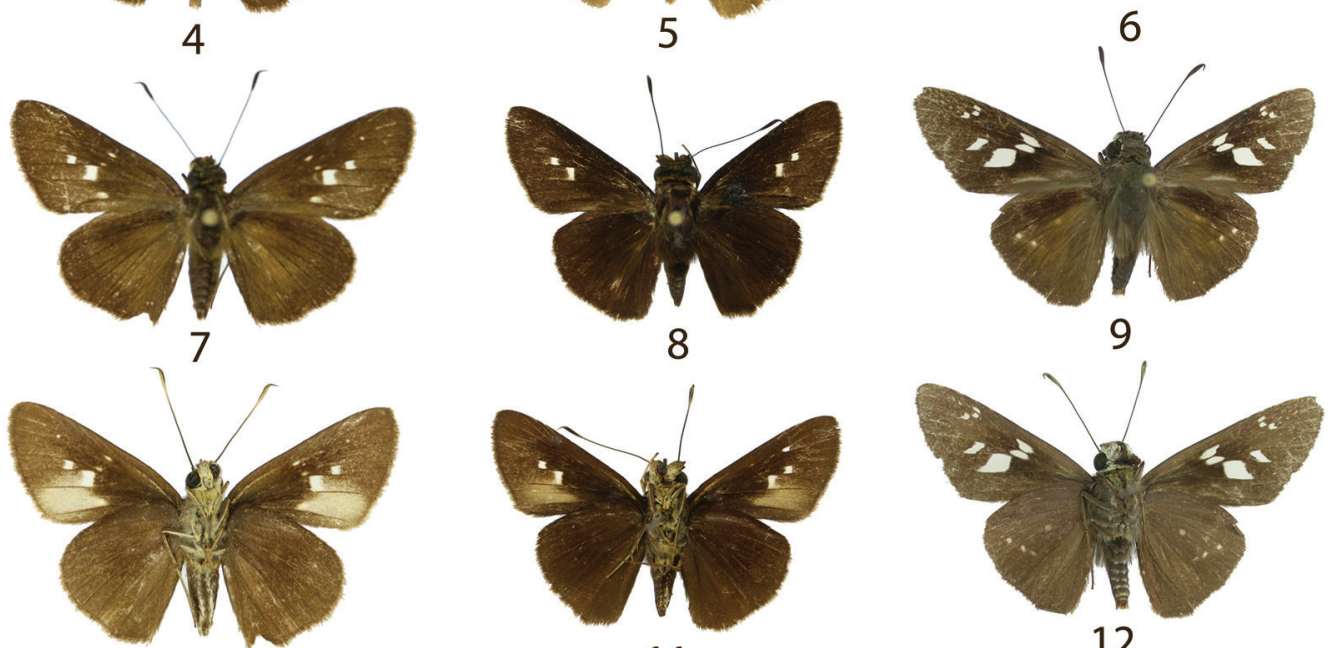

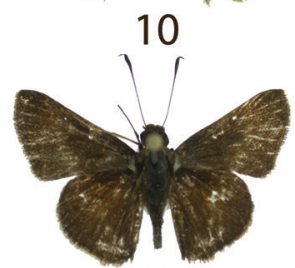

13

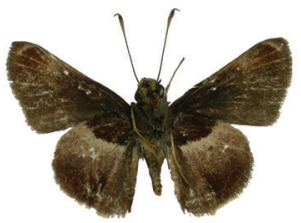

16

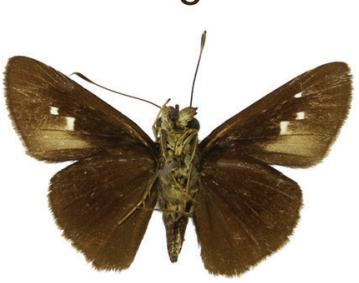

11

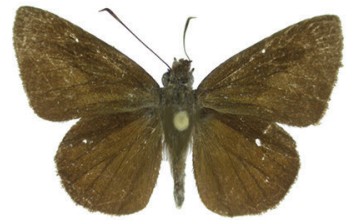

14

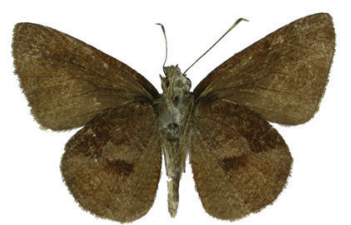

17

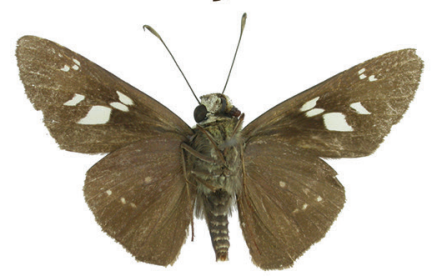

12

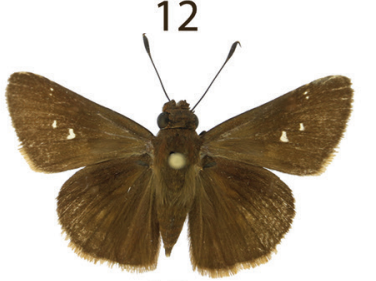

15

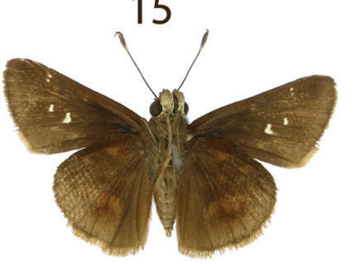

18

Plate 4. Hesperiinae 2: 1: Papias dictys (d), 2: Papias subcostulata ( $9 \mathrm{~d}), 3:$ Mucia zygia (d), 4: Papias subcostulata (ðv), 5: Papias subcostulata (v), 6: Mucia zygia (v), 7: Cynea cynea (아), 8: Cynea cynea (ôd), 9: Rhinthon osca (d), 10: Cynea cynea (†े), 11: Cynea cynea (ふ̊v), 12: Rhinthon osca (v), 13: Remella rita (d), 14: Synapte salenus (d), 15: Quinta cannae (d), 16: Remella rita (v), 17: Synapte salenus (v), 18: Quinta cannae (v). 

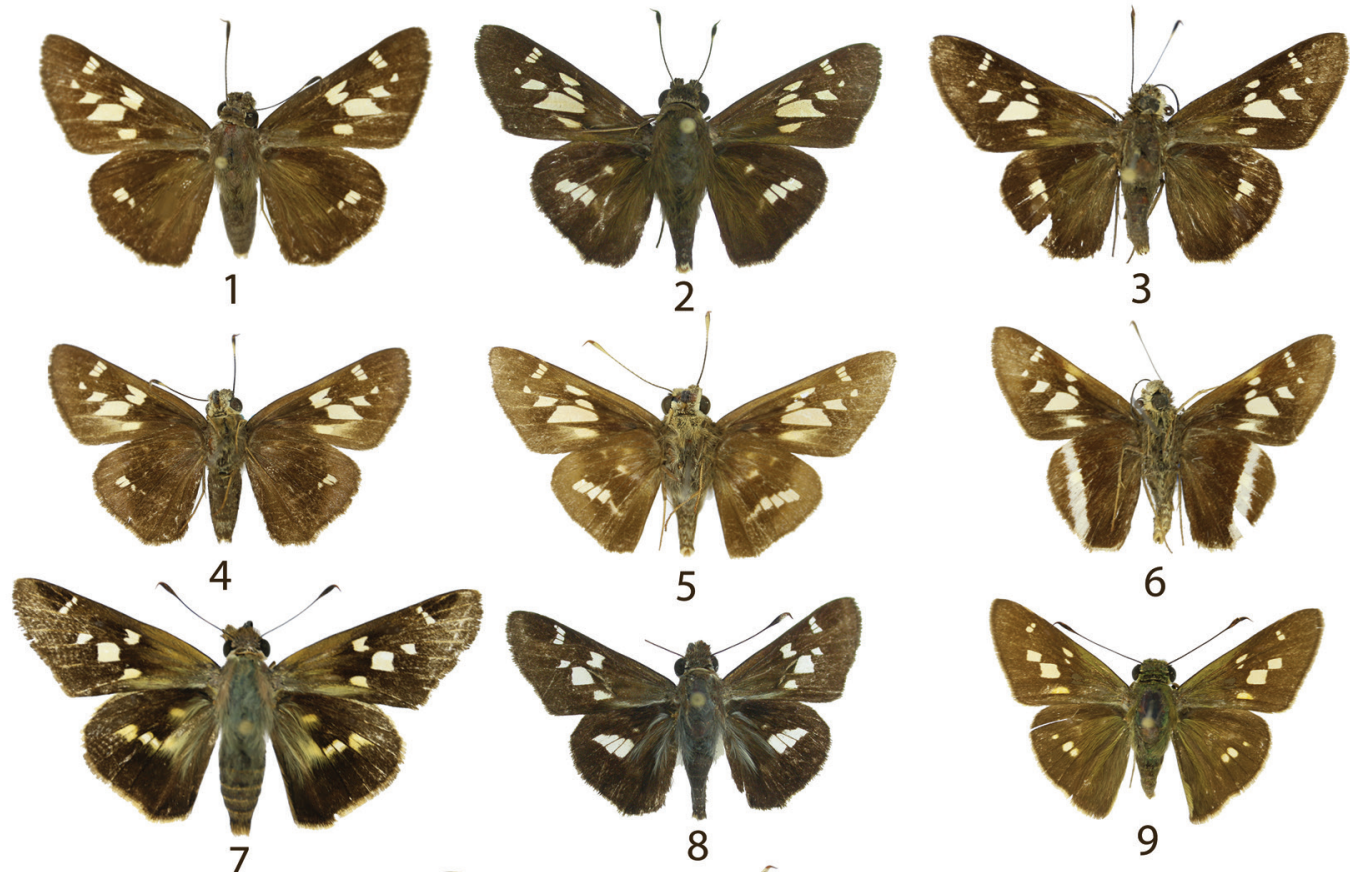

3
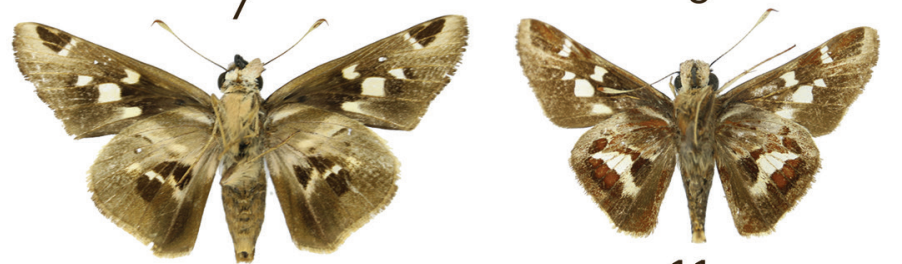

10
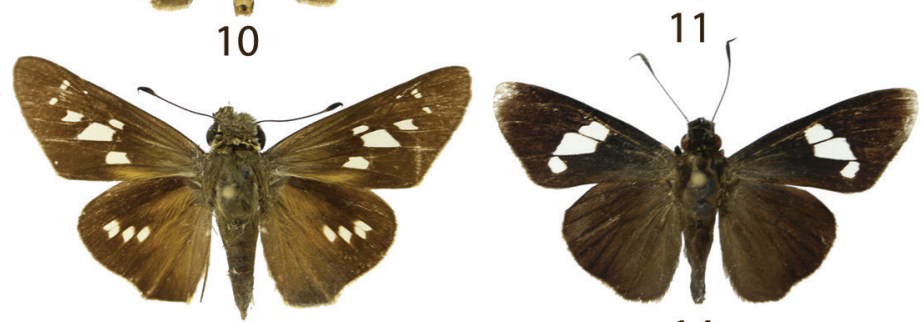

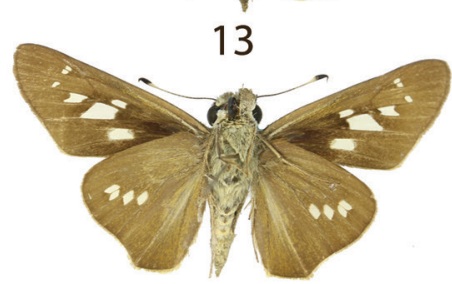

16

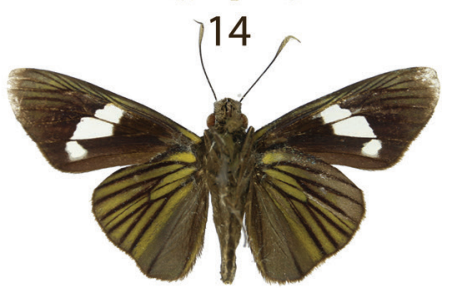

17

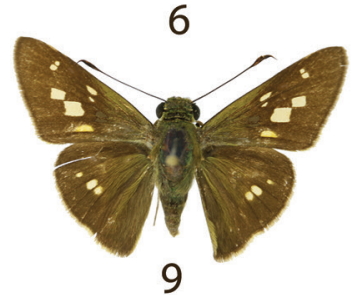

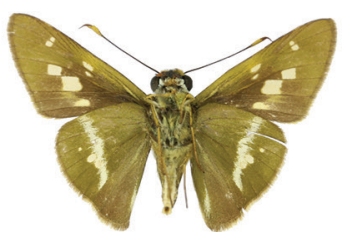

12

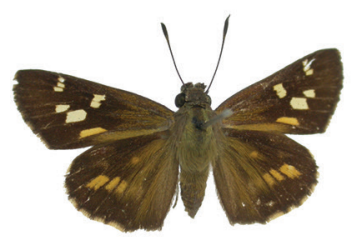

15

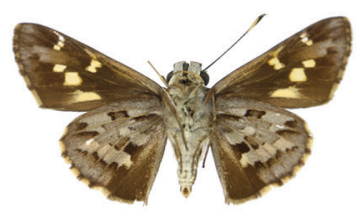

18

Plate 5. Hesperiinae 3: 1: Vacerra lacheres $(+\mathrm{d})$, 2: Vacerra egla $(3 \mathrm{~d})$, 3: Vacerra caniola $(\mathrm{d})$, 4: Vacerra lacheres $(\mathrm{v})$, 5: Vacerra egla (v), 6: Vacerra caniola (v), 7: Thespieus dalman (d), 8; Thespieus macareus (d), 9: Niconiades nikko (d), 10: Thespieus dalman (v), 11: Thespieus macareus (v), 12: Niconiades nikko (v), 13: Calpodes ethlius (d), 14: Synale cynaxa (d), 15: Halotus rica (d), 16: Calpodes ethlius (v), 17: Synale cynaxa (v) y 18: Halotus rica (v). 


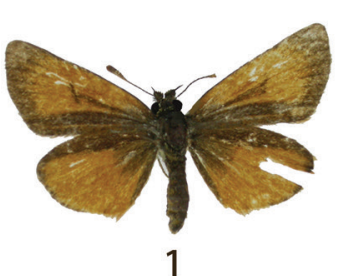

1
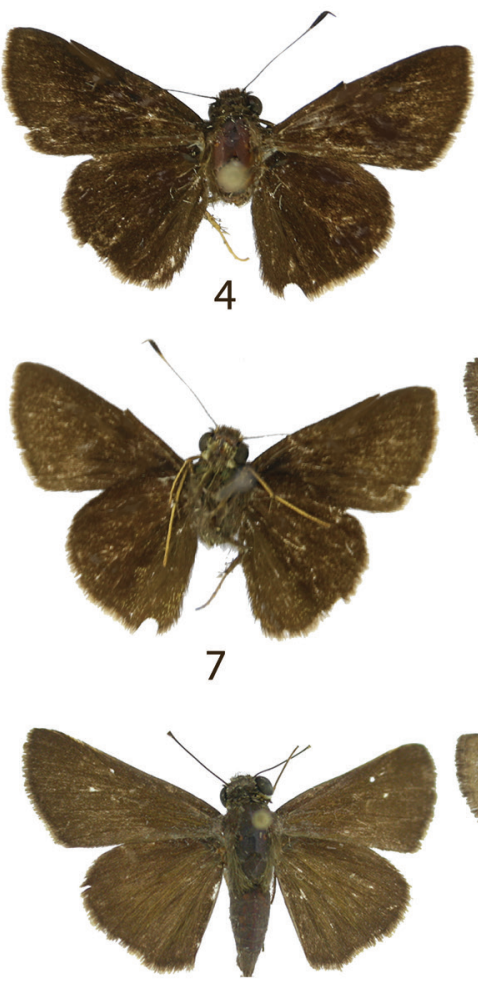

10

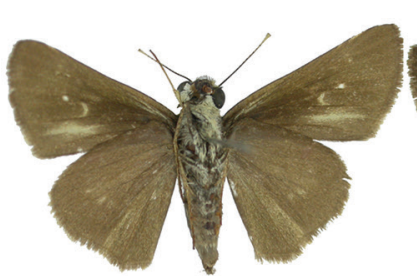

13
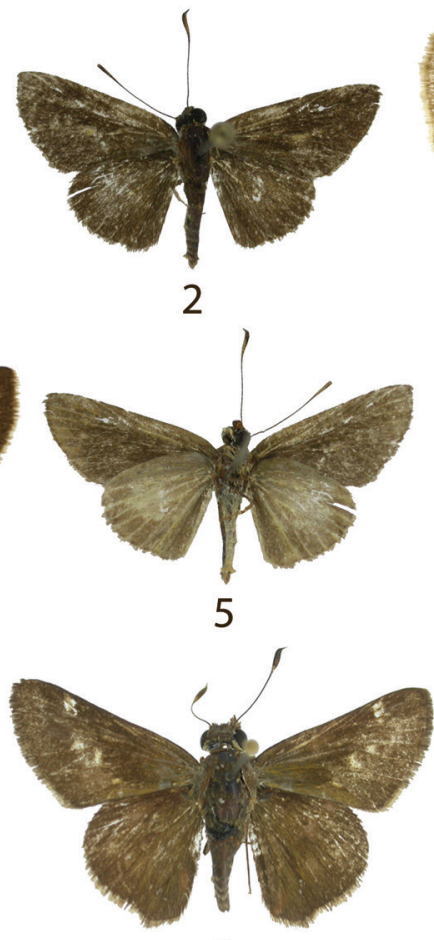

8

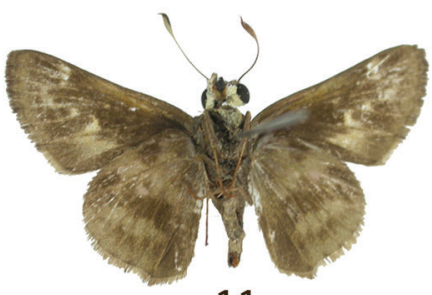

11

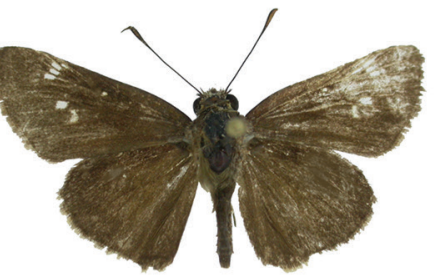

14
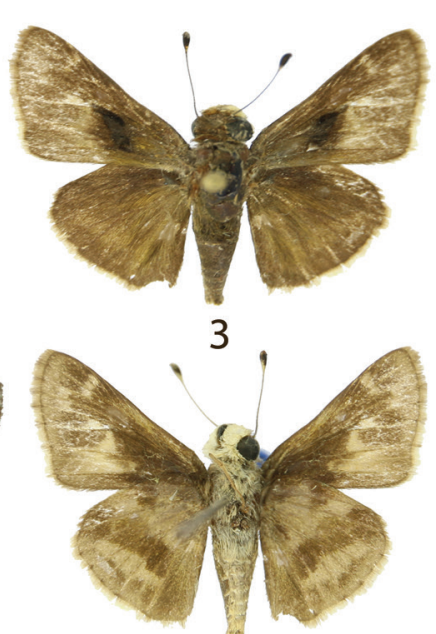

6
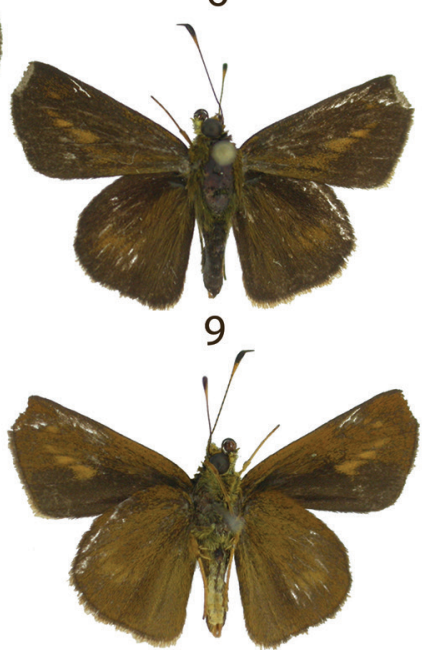

12

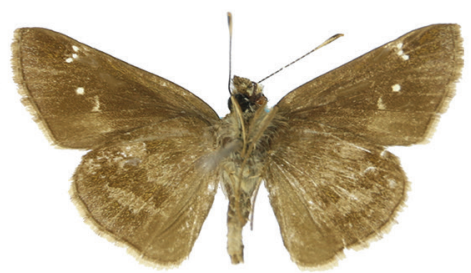

15

Plate 6. Hesperiinae 4: 1: Ancyloxypha arene (d), 2: Callimormus juventus (d), 3: Pompeius pompeius (d), 4: Mnasitheus sp. (d), 5: Callimormus juventus (v), 6: Pompeius pompeius (v), 7: Mnasitheus sp. (v), 8: Polites vibex vibex (d), 9: Corticea lysias lysias (d), 10: Conga chydaea (d), 11: Polites vibex vibex (v), 12: Corticea lysias lysias (v), 13: Conga chydaea (v), 14: Cymaenes odilia trebius (d), 15: Cymaenes odilia trebius (v). 


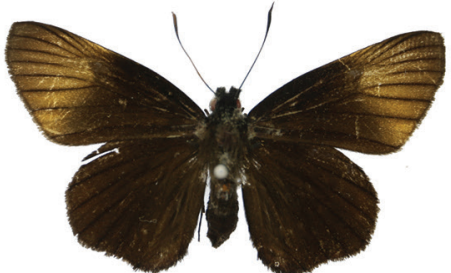

1

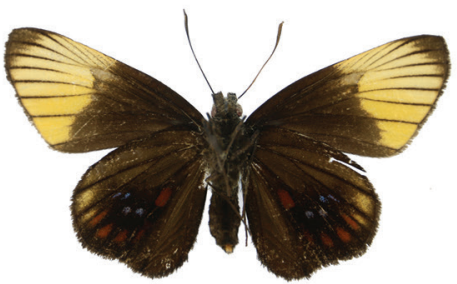

4

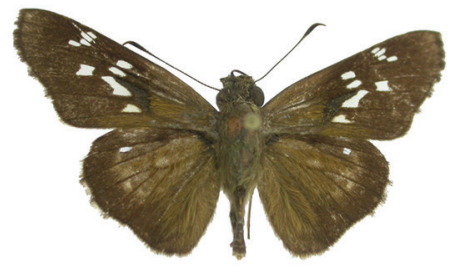

7

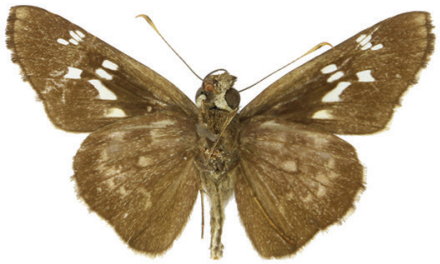

10

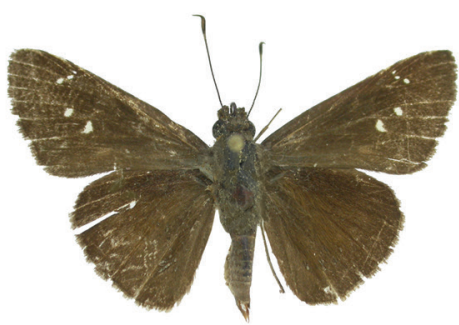

13
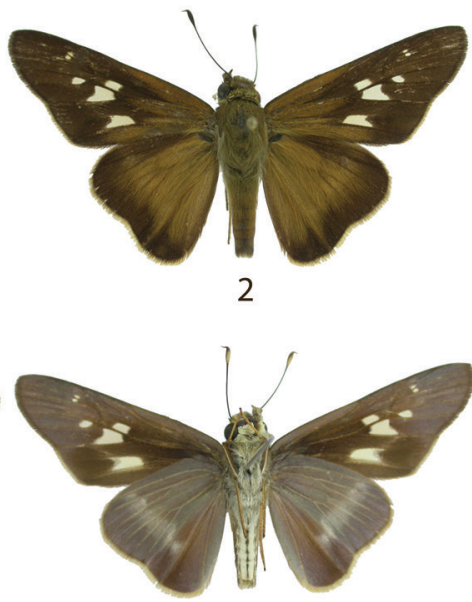

5

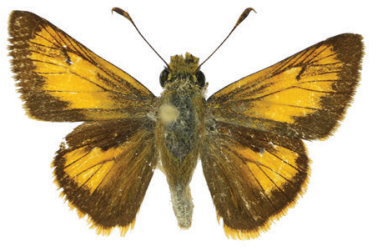

8

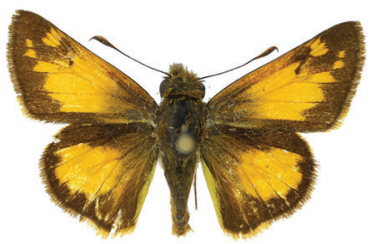

11

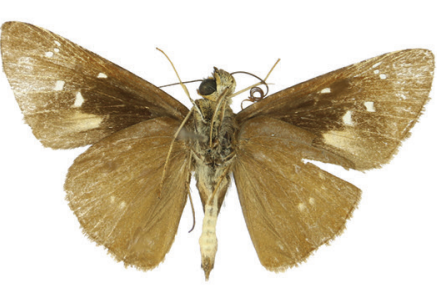

14

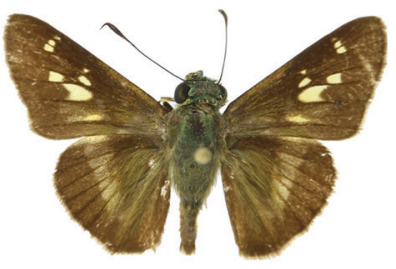

3

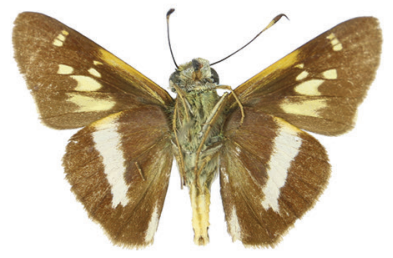

6

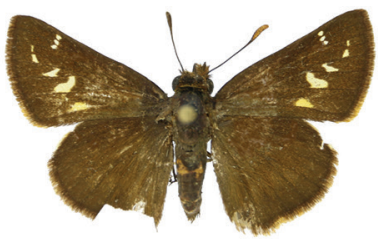

9

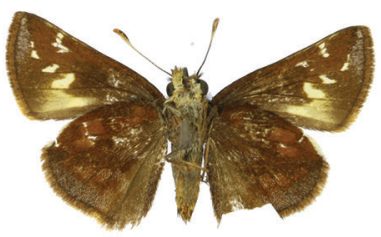

12

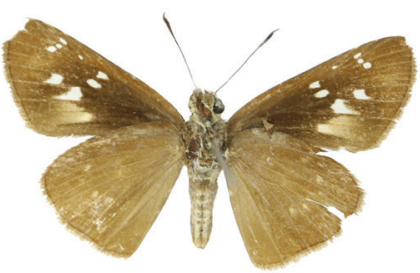

15

Plate 7. Hesperiinae 5: 1: Dion gemmatus (d), 2: Panoquina evadnes (d), 3: Oxynthes corusca (d), 4: Dion gemmatus (v), 5: Panoquina evadnes (v), 6: Oxynthes corusca (v), 7: Naevolus orius (d), 8: Buzyges rolla (ðd), 9: Poanes zabulon ( $9 \mathrm{~d})$, 10, Naevolus orius (v), 11: Poanes zabulon $(\widehat{\partial d}), 12$ : Poanes zabulon $(+\mathrm{v}), 13$ : Cobalopsis nero $(\widehat{\jmath}), 14:$ Cobalopsis nero (ぷv), 15: Cobalopsis nero $(+\mathrm{P})$. 